\title{
8. STRESS TENSORS AT THE TOE OF THE NANKAI ACCRETIONARY PRISM: AN APPLICATION OF INVERSE METHODS TO SLICKENLINED FAULTS ${ }^{1}$
}

\author{
S.J. Lallemant, ${ }^{2}$ T. Byrne,${ }^{3}$ A. Maltman, ${ }^{4}$ D. Karig, ${ }^{5}$ and P. Henry ${ }^{2}$
}

\begin{abstract}
Drilling at Site 808 (ODP Leg 131) provided an extensive record of the discrete brittle structures (small faults and shear bands) at the toe of the Nankai accretionary complex. Brittle failure is occurring throughout the hole, although most of the deformation has been observed between the frontal thrust and the décollement (from 365 to $963 \mathrm{mbsf}$ ). Brittle failure occurs in the turbiditic trench fill ( 0 to $600 \mathrm{mbsf}$ ) but also in the ash-bearing hemipelagites from the upper Shikoku Basin ( 600 to $800 \mathrm{mbsf})$ and the ash-free hemipelagites of the lower Shikoku Basin sequences, down to the décollement ( $963 \mathrm{mbsf}$ ). The geometry of the tectonic features has been recorded in a local frame related to the core liner and then corrected to an absolute frame by the use of paleomagnetic measurements. We used the resulting geometry of homogeneous populations of slickenlined faults to estimate the reduced stress tensor. The main result is to show three consistent stress patterns. Most of the fault clusters from the frontal thrust down to the décollement are in good agreement with a compressional regime with a northwest-trending $\sigma_{1}$ (azimuth $\mathrm{N} 305^{\circ}$ to $\mathrm{N} 315^{\circ}$ ). The compression direction is thus roughly parallel to the local direction of the relative convergence. It is also perpendicular to the trend of the anticlinal ridges. Discrete faults, locally appearing as clusters (e.g., $30 \mathrm{~m}$ above the décollement) agree with a quite different compression direction (west-southwest-east-northeast) and are restricted to the hemipelagic sequences above the décollement. They could be related to the heterogeneous internal deformation of this layer. Although isolated normal faults exist, their occurrence as clusters is restricted to the Shikoku Basin hemipelagic sequences and indicate a east-west to northwest-southeast extension axis $\left(\sigma_{3}\right)$. Finally, the analysis of Mohr diagrams related to the best-fitting tensors shows some similarities and differences between the fault populations of the turbidite and those of the hemipelagite sequences. The angle of friction corresponding to $95 \%$ of the data is $30^{\circ} \pm 5^{\circ}$, whereas including the remaining $5 \%$ in turbidites and hemipelagites would result in a lower friction angle $\left(18^{\circ} \pm 8^{\circ}\right)$. The major difference concerns the angle between conjugate sets which are about $60^{\circ}$ in the turbidites and lower $\left(35^{\circ}-40^{\circ}\right)$ in a $200 \mathrm{~m}$ thick zone above the décollement and can be explained by higher fluid pressure in the hemipelagites or by odd mechanical properties of this hemipelagic material.
\end{abstract}

\section{INTRODUCTION}

During Leg 131, drilling at Site 808 (Fig. 1) was devoted to the study of the relations existing between deformation and fluid circulation at the toe of the Nankai accretionary wedge (Taira et al., 1992). Hole $808 \mathrm{C}$, off Shikoku, succeeded in penetrating the frontal thrust and the décollement down to the oceanic basement, around $1290 \mathrm{mbsf}$ (meters below seafloor) (Fig. 2). One of the goals of the shipboard structural geologists was to record the precise geometry of most of the mesostructures (i.e., the tectonic features at the scale of the core). Based on their internal fabric, Maltman et al. (this volume) proposes a classification of the discrete shear-related structures into three types: "kink-like" deformation bands, "shear-zone-like" deformation bands, and small faults. We focus our attention on the two last types that bear slickenlines on their walls and therefore indicate the direction of the motion. We will later refer to these features simply as faults. Using the paleomagnetic measurements we were able to estimate confidently the absolute orientations of the fault plane azimuths and slickenline trends. So it becomes reasonable to use the geometry of these slickenlined faults to get quantitative information about the stress tensor at the time of the failure. Because recovery was good overall and we recorded the maximum amount of quantitative information about brittle deformation, Site 808 is probably the best location to describe

' Hill, I.A., Taira, A., Firth, J.V., et al., 1993. Proc. ODP, Sci. Results, 131: College Station, TX (Ocean Drilling Program).

${ }^{2}$ Laboratoire de Géologie, Ecole Normale Supérieure, 24 rue Lhomond, 75005 Paris, France.

${ }^{3}$ Dept. of Geology and Geophysics, University of Connecticut, Storrs, CT 06268 , U.S.A.

${ }^{4}$ Institute of Earth Studies, University College of Wales, Llandinam Bld, Penglais, Aberystwyth, SY23 3DB, United Kingdom.

${ }^{5}$ Dept. of Geological Sciences, Cornell University, Ithaca, NY 14853, U.S.A. the depth distribution of the stresses in a simple compressional system above a décollement.

The plate kinematics of this convergent boundary are reasonably well known: the Shikoku Basin, underthrust below the Japanese margin of the Eurasian Plate belongs to the Philippine Sea plate (or PSP). Thus, we can investigate the relationship between plate kinematics (namely, the local convergence velocity) and the local stress pattern. Several models have been published on the instantaneous relative motion of the PSP and the Eurasian plate. The discrepancies between the models are mainly due to the fact that all of the boundaries of the PSP are convergent. However the consequences of these discrepancies concern the local subduction rates more than the directions. As shown by Table 1 , the computed azimuth of the local convergence vector at Site 808 lies between N $309^{\circ}$ and N $315^{\circ}$.

\section{METHODS}

\section{Criteria of Motion along Faults}

A systematic search for indicators of the direction and of the sense of motion along the fault planes was carried out onboard. We carefully examined the slickenlines on the fault planes to discard drillinginduced features. Although recent theoretical developments allow an interpretation of curved slickenlines (Twiss et al., 1991), we systematically discarded such features. The self-consistency of the data set after core reorientation is probably the best justification for our data selection. Some unambiguous senses of motion have been deduced from the apparent throw of geometrical markers like sedimentary beds, burrows, or earlier deformation bands. Some criteria were also found on the walls of slickenlined fault planes. These are either slickensides, small patches of finite-length fibers (Arthaud and Mattauer, 1969; McClay, 1987), or, more commonly, Riedel-type secondary faults across the walls (Petit et al., 1983; McClay, 1987). Examples of both kinds of structures are shown in Figure 3 as well as their interpretation. 


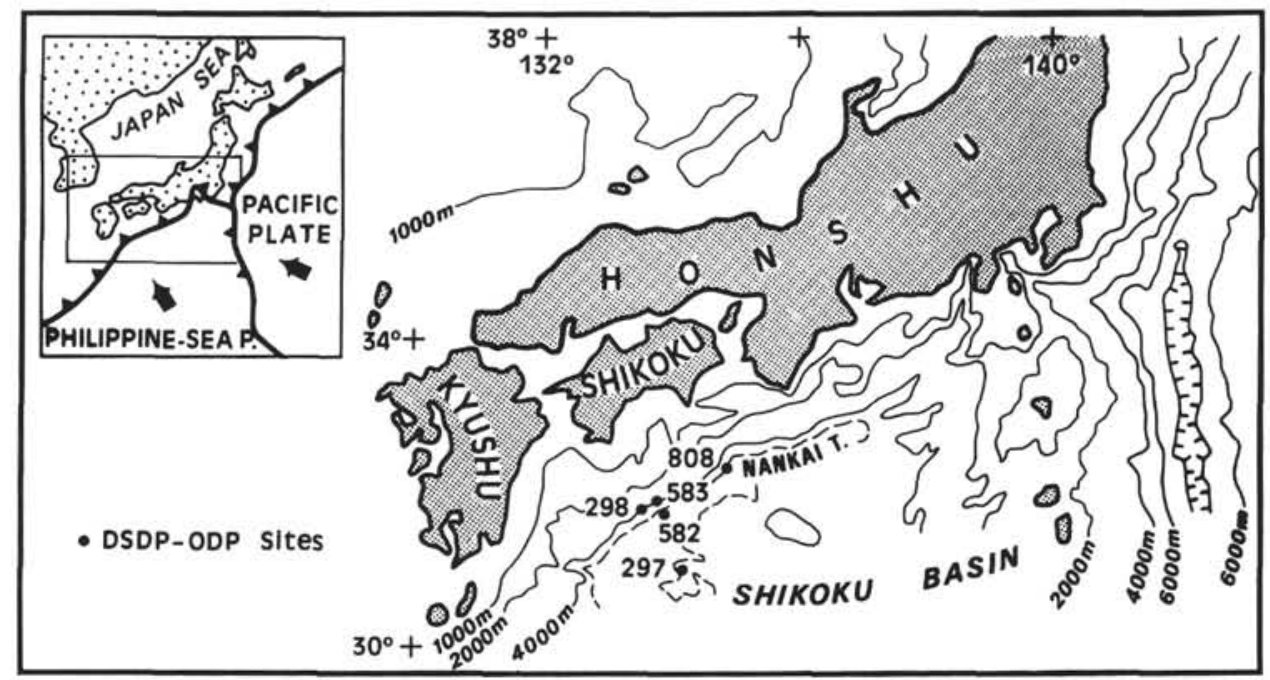

Figure 1. General location of Site 808 in the Nankai Trough (ODP Leg 131).

\section{Orientation of the Structures}

Leg 131 was the first opportunity to extensively use paleomagnetic data to orient the brittle discrete structures and thus to quantify the stress field at the toe of an active convergent margin. The standard procedure to obtain oriented structures has been described in the section "Structural Geology" (Shipboard Scientific Party, 1991, p. 3944). We measured the orientation of all the structures in a local reference frame relative to the core liner. We then used the paleomagnetic data acquired routinely along the core sections to correct the effect of the rotation of the cores induced by drilling operations (Fig. 4). In the case of some core sections with numerous faults bounding small individual pieces, we ran separately the fault-bounded pieces in the cryogenic magnetometer.

B. Owens and R. Lu (in Shipboard Scientific Party, 1991, p. 126-127) give a review of the principal assumptions made when using the paleomagnetic data to orient the core liner reference frame. These basic assumptions are that the samples contain a stable component of remanent magnetization, also that corrections have been made for any tectonic modification of the remanence subsequent to the remanence acquisition and finally that the direction of the paleofield in which the remanence was acquired is known. We can easily admit as they do that the geomagnetic field was stable around a north-south oriented axis since the last few tens of millions of years, during the deposition of the sedimentary sequence. However, it is necessary to take into account the tectonic corrections, especially the consequences of the progressive rotation (within the horizontal plane) of remanent magnetization due to plate motion (e.g., Perroud, 1982).

Is our assumption that the remanent magnetization of the Site 808 sediments did not significantly rotate since the deposition of the sequence in agreement with the well-documented recent absolute motion of the Philippine Sea Plate? We try in this section to evaluate the maximum value of this rotation. One should recall that the sedimentary sequence down to the décollement was deposited since the Miocene-Pliocene Boundary (i.e., about $5 \mathrm{Ma}$ ) and that the total duration of the sediment deposition sequence, including the slowly deposited underthrust, did not exceed 13.6 Ma. All the recent estimates of the instantaneous motion of the (PSP) relative to Eurasia (e.g., Seno, 1977; Ranken et al., 1984; Huchon, 1986; Seno et al., 1987) imply that the Nankai Trough is fairly close to the Eulerian pole. On the other hand, Vacquier and Uyeda (1967) have shown that the remanent magnetization of some seamounts close to the Shikoku Basin fossil spreading center (and supposedly of the same age as the youngest magnetic anomalies) have not suffered any net rotation.
More recently, Chamot-Rooke et al. (1989), their study based on a skewness analysis of the Shikoku Basin anomalies, have also claimed that no significant rotation of the remanent magnetization have occurred since about $20 \mathrm{Ma}$ (anomaly 6). There is a general agreement on the idea that the PSP motion relative to Eurasia changed in the late Tertiary from an almost northward drift to a recent northwestward motion. On the other hand, the question of the exact time when this change occurred is subject to discussion. In their classical paleogeographic reconstructions of the PSP, Seno and Maruyama (1984) suggested that the change occurred sometime between 10 and $5 \mathrm{Ma}$. This timing has been recently refined on the basis of field studies of the deformation in the vicinity of the plate boundary. In the Taiwan collision zone, Barrier (1985) proposes a major change between 6 and $4 \mathrm{Ma}$, whereas Huchon and Angelier (1987) claimed that the major change took place in the Izu collision zone about $2 \mathrm{Ma}$. To estimate the consequences of this recent motion, we computed the absolute instantaneous motion of the PSP in the Hot Spot reference frame corresponding to three kinematic models (Ranken et al., 1984; Huchon, 1986; Seno et al., 1987) for the PSP/Eurasia motion combined with the Eurasia/Hot Spot rotation from the classical AM1-2 global model (Minster and Jordan, 1978). Extrapolating this motion back in time, we computed the expected rotation of a magnetization vector induced by such a finite rotation in both cases $(2$ and $5 \mathrm{Ma}$ duration of this recent pattern). The results, given in Table 2, show clearly that the maximum apparent rotation of the declination is only of the order of the uncertainty in our determination of the principal stresses. For completeness we did the same computation with the Eurasia/Hot Spot rotation from the recent HS2-NUVEL1 (Gripp and Gordon, 1990) which gives similar results (differences are smaller than $1^{\circ}$ ) and therefore leads to the same conclusion.

\section{Stress Tensor Inversion}

Assuming that some fault populations have moved in a homogenous stress pattern, we can relate their kinematics to the geometry of the stress tensor. Two different methods have been used routinely. The first one is a graphical approach developed by Mercier et al. (1976) and Angelier and Mechler (1977) and called by the latter the "rightangle dihedra" method or "P and T dihedra." This approach, which is basically a statistical study of the $\mathrm{P}$ and $\mathrm{T}$ axes of the slickenlined faults, typically gives weak constraints on the stress tensor (especially when most faults are close to conjugate sets), but result in a rapid estimate of the stress tensor. An example is given in Figure 7. Since Wallace (1951) and Bott (1959) computed the oblique slip on a fault 

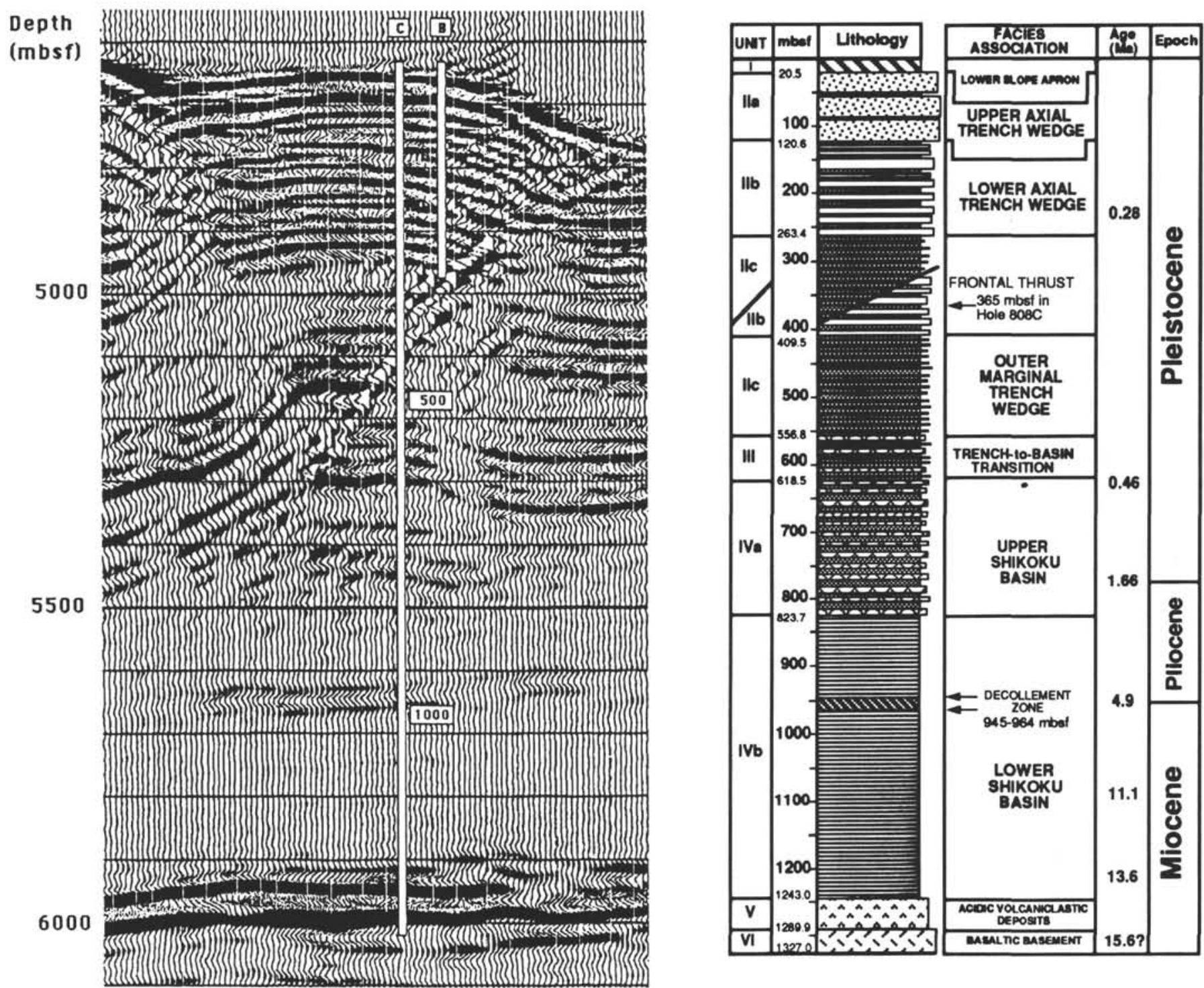

Figure 2. Detail of a multichannel seismic section across the toe of the Nankai accretionary wedge (from Moore et al., 1990) showing Holes 808C and 808B of Leg 131 as well as age and lithofacies distribution (Taira et al., 1992).

plane suffering a given stress tensor, many authors addressed the inverse problem (e.g., Carey and Brunier, 1974; Armijo and Cisternas, 1978; Angelier, 1979 and 1984; Etchecopar et al., 1981; Angelier et al., 1982; Gephart and Forsyth, 1984). Basically, most of these approaches assume that the slip direction is parallel to the maximum shear stress on the fault plane. Although Twiss et al. (1991) suggested that this assumption is not systematically valid, it gives practical results. Most of the above methods are based on the minimizing of a function of the angle between the observed direction of movement and the predicted maximum shear stress direction. In our study we have used the method of Angelier (1984), which minimizes the squared tangent of this angle.

\section{TECTONIC SETTING AND DEPTH DISTRIBUTION OF THE FAULTS}

One striking result of the structural analysis at Leg 131 Hole 808C is to show that apart from the highly brecciated zones corresponding to the domains of highest strain (décollement and frontal thrusts), the brittle structures are widely distributed. However, the very abundant faulting pattern is not evenly distributed with depth, but, rather, most of the mesoscopic brittle deformation is clustered in some moderately deformed zones (Fig. 5). Two clusters of mesoscopic structures are related to the most obvious features of the area: the frontal thrust (Core 131-808C-8R around $365 \mathrm{mbsf}$ ) and the décollement (Core 131$808 \mathrm{C}-69 \mathrm{R}$ around $900 \mathrm{mbsf}$ ). However, there are two additional peaks of brittle deformation that are apparently not correlated with any large-scale deformation zone at the scale of the seismic section. Both peaks are instead correlated with major lithologic boundaries, the first one corresponding to the base of the trench fill system (Core $131-808 \mathrm{C}-38 \mathrm{R}$ around $560 \mathrm{mbsf}$ ) and the second (Core 131-808C$51 \mathrm{R}$ around $800 \mathrm{mbsf}$ ) being correlated with the boundary between the ash-bearing hemipelagic mudstones from the upper Shikoku Basin unit and the ash-free hemipelagites from the lower Shikoku Basin (see Fig. 2 for the lithofacies distribution).

\section{ORIENTATION OF THE PRINCIPAL STRESSES}

We show in Table 3 and in Figures 6 to 11 the most internally consistent fault populations and their best-fitting stress tensor solu- 
Table 1. Local linear velocity at Site 808 for the instantaneous motion: Philippine Sea Plate/Eurasian Plate. Site 808 location is $32.34^{\circ} \mathrm{N}$ and $134.94^{\circ} \mathrm{E}$.

\begin{tabular}{ccccccc}
\hline & \multicolumn{2}{c}{ Eulerian pole } & & \multicolumn{3}{c}{ Linear velocity } \\
\cline { 2 - 3 } \cline { 5 - 7 } & $\begin{array}{c}\text { Latitude } \\
{ }^{\circ} \mathrm{N}\end{array}$ & $\begin{array}{c}\text { Longitude } \\
{ }^{\circ} \mathrm{E}\end{array}$ & & $\begin{array}{c}\text { Angular velocity } \\
\text { degrees/Ma }\end{array}$ & $\begin{array}{c}\text { Azimuth } \\
{ }^{\circ} \mathrm{E}\end{array}$ & $\begin{array}{c}\text { Velocity } \\
\mathrm{cm} / \mathrm{yr}\end{array}$ \\
\hline 1 & 37.0 & 141.0 & & 1.20 & 315.2 & 1.6 \\
2 & 38.0 & 142.0 & & 1.95 & 313.6 & 3.0 \\
3 & 49.4 & 158.1 & & 1.09 & 308.5 & 4.9
\end{tabular}

Note: The angular velocities are positive clockwise.

${ }^{a} 1$ = Ranken et al. (1984); 2 = Huchon (1986); 3 = Seno et al. (1987).

tions obtained by the inversion process. These solutions can be split into three homogeneous groups: two groups of compressional regimes (with $\sigma_{1}$ almost horizontal) and one group of extensional regime. One compressional regime show a $\sigma_{1}$ roughly perpendicular to the strike of the frontal fold and thrust system (i.e., about $\mathrm{N} 045^{\circ}$ ), the other one having a $\sigma_{1}$ roughly parallel to this strike.

\section{Shortening Perpendicular to the Strike}

This tectonic regime seems the more widely distributed along the Hole $808 \mathrm{C}$ samples, from Core 131-808C-11R down to Core 131808C-69R (950 mbsf at the décollement level). We selected the most consistent data set in Figures 6, 7, and 8. They show that the results in terms of the azimuth of the $\sigma_{1}$ axis are almost exactly the same from one core to the other, whether the faults are purely reverse (dip-slip), oblique-slip, or almost strike-slip. The solutions are stable and close to the one obtained by the crude PT dihedra method, as seen by the comparison of Figures 6 and 7. No significant changes were induced by changing the function to be minimized (sine or tangent). The average $\sigma_{1}$ value (around $\mathrm{N} 310^{\circ}$ ) produced by this surprisingly consistent inversion is not completely unexpected and corresponds both to the local plate convergence vector (see introduction and Table 1) and to the perpendicular to the strike of the major large-scale tectonic features such as the frontal thrust and the anticlinal ridges in this part of the wedge. Figure 9 shows that this compression is also the one acting within the décollement.

\section{Shortening Parallel to the Strike}

One of the most surprising results of our brittle tectonic study at Site 808 was the observation of reverse fault clusters that indicate a shortening roughly parallel to the strike of the frontal thrust. The best example is located only $30 \mathrm{~m}$ above the décollement (Core 131-808C66R in Fig. 9). In this core, most of the faults have an unknown sense of motion, however, the faults whose sense is known are reverse; thus we assume all the faults to be reverse and then obtain a stress tensor with $\sigma_{1}$ west-southwest-east-northeast (azimuth $\mathrm{N} 252^{\circ}$ ), close to the strike of the large-scale structures. This stress regime is not restricted to a single core. Figure 10 shows the case of Core $131-808 \mathrm{C}-64 \mathrm{R}$ (50 $\mathrm{m}$ above the décollement) which shows an heterogeneous fault population. The upper diagram (64R) shows the stress tensor inversion of a subset of faults with a known reverse sense of the motion. This data set comprises purely reverse and almost strike-slip planes that give a nice tensor inversion (the average angle between actual and computed maximum shear stress is smaller than all the cores that were evaluated, see Table 3). Taking into account that very few of the faults with a known sense of motion had a normal throw, we assumed that all the unknown senses of motion were reverse. A stress tensor inversion of such a composite data set (64R-u) gives a relatively poor result with a east-trending $\sigma_{1}$, unknown in the other cores. We can get a much better result by sorting automatically the data (method developed by Angelier and Manoussis, 1980). We end up with two homogeneous populations corresponding to the same tensors as Core 131-808C-66R (case of 64R-u1 in Fig. 10) and 131-808C-69R (case of 64R-u2). Although data are too scarce to perform stress tensor inversion, similar reverse fault planes consistent with a compression parallel to the strike were found up to the top of the Shikoku Basin sequences.

\section{Extensional Regime}

Small normal faults have been observed almost from the top to the bottom of the drilling sequence, some discrete features being probably related to the sediment compaction. However, in the upper part of the Shikoku Basin, these normal faults are clustering and allow us to get stress tensors. As seen on Figure 11, where all the faults of the diagrams have a known normal motion, most of the normal faults have a moderate to high dip angle. All of the $\sigma_{3}$ directions lie between east-west and northwest-southeast.

\section{Depth Distribution of the Stress Regimes}

The distribution of the structures related to each of these three groups of stress tensors is displayed in the synthetic diagram of Figure 12. Although this diagram does not show the relative importance of each stress regime (in terms of strain), it shows the relationships of these stress regimes with both the lithological boundaries and the large-scale tectonic features (high strained zones of the frontal thrust and the décollement). We see first, that no significant shortening occurs below the décollement, whereas extensional tectonics are observed deep in the sequence. Second, the shortening perpendicular to the strike is distributed over the whole domain above the décollement whereas shortening parallel to the strike is restricted to the hemipelagic sequences.

\section{MOHR DIAGRAMS: HINTS ON PORE PRESSURE?}

As the magnitude of the stresses does not influence the direction of slip along a fault plane, the inversion procedures give a reduced stress tensor (i.e., a dimensionless stress tensor where $\sigma_{1}=1$ and $\sigma_{3}$ =0; Angelier, 1984 and 1989). However, once the directions of the principal stresses and the shape of the tensor, known as the parameter $\Phi=\left(\sigma_{2}-\sigma_{3}\right) /\left(\sigma_{1}-\sigma_{3}\right)$, have been determined from an inversion method, it is possible to plot on a Mohr diagram the stress (normal stress $\sigma_{n}$ and shear stress $\tau$ ) on every individual fault (see Table 4 for stress parameters). Of course, the actual size of the Mohr circle and its position with respect to the origin of abscissas (zero normal stress) is not known from the inversion procedure, but, as shown by Angelier (1989), these plots provide clues to estimate the value of the principal stresses. If the sample has just reached failure, newly formed faults are expected to plot near the point of the Mohr circle tangent to the failure envelope, which corresponds to conjugate sets (see Fig. 13). If the failure curve is known, then the determination of stress magnitude is possible. Reactivated faults plot within the circle, or on the circle away from the tangent point $(\mathrm{C})$. Let us assume that slip along weakness planes such as preexisting faults (and possibly joints and strata bounds) is controlled by a linear friction law:

$$
\tau=\mu \sigma_{\mathrm{n}}
$$

where $\tau$ is the shear stress required to cause sliding, $\sigma_{\mathrm{n}}$ is the normal stress and $\mu$ is the friction coefficient. Byerlee (1978) showed that for normal stresses between 10 and $200 \mathrm{MPa}$, friction is between a maximum value (corresponding in stick-slip behavior to the stress at the beginning of sudden slip) $\mu=0.85$ and a minimum (initial friction, corresponding in stick-slip behavior to the stress at the onset of slow slip) of about $\mu=0.5$, independently of rock type (except for certain clays, particularly smectites) and of fracture roughness. Then, all points representative of faults with sliplines compatible with the cal- 
A

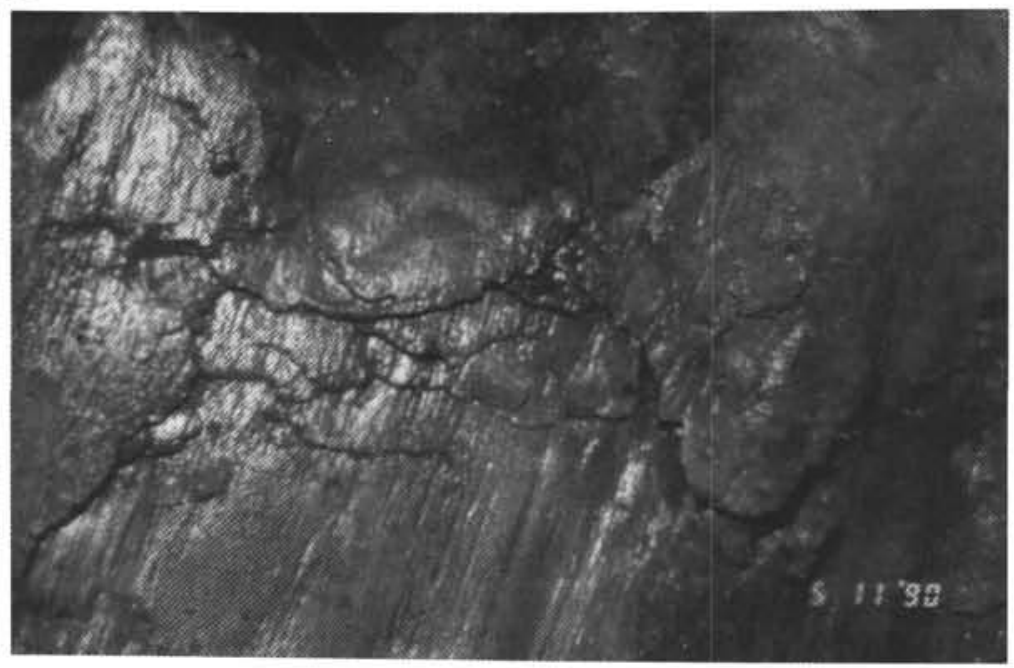

B

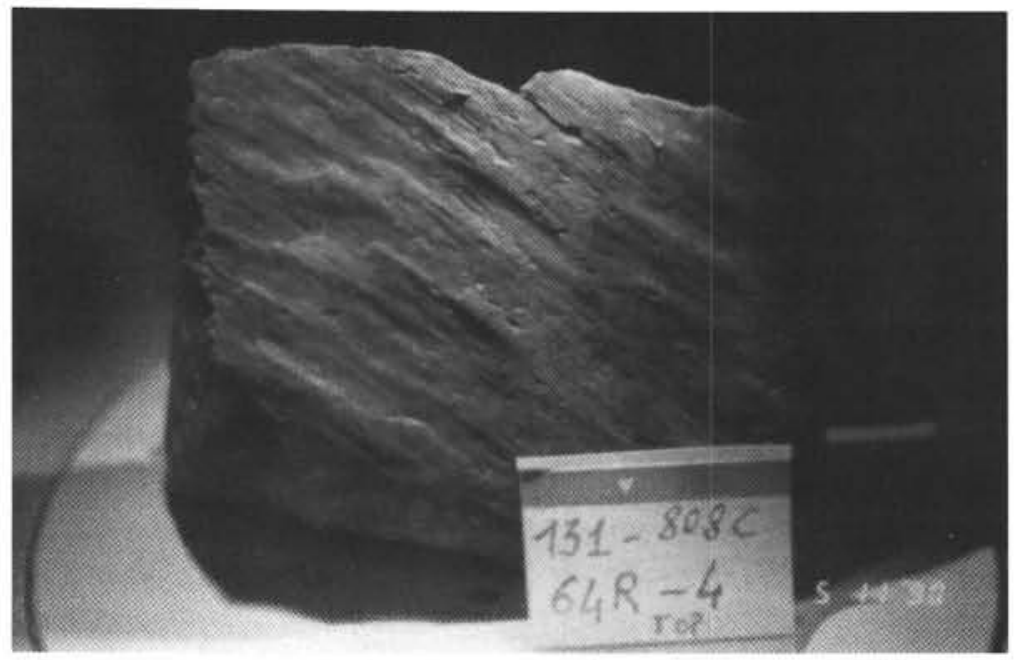

C

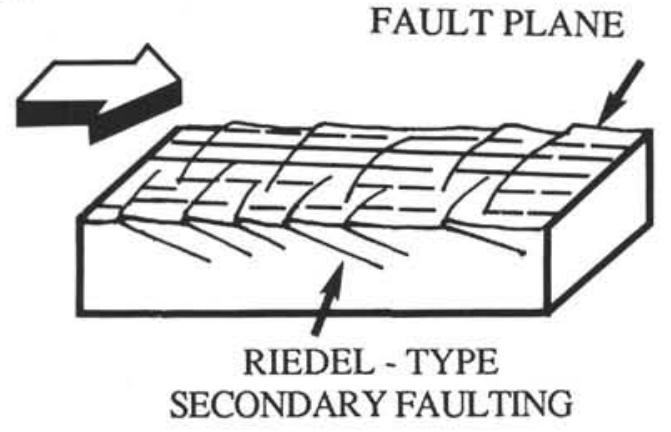

D

\section{SLICKENSIDES}

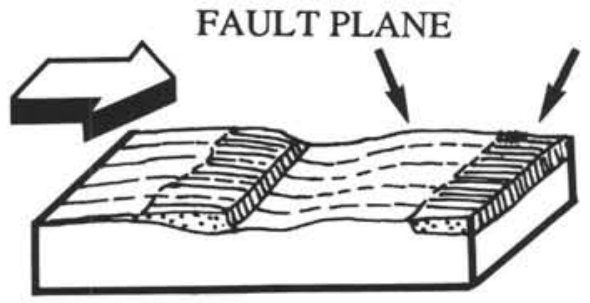

Figure 3. Two examples of slickenlined fault planes. A. Fault plane with associated Riedel-type steps. B. Fault with slickensides (small surfaces of finite length fibers). C and D. Sketches explaining the geometric relations between the small steps and the motion of the upper fault wall shown by the large arrow (modified from Petit et al., 1983). 

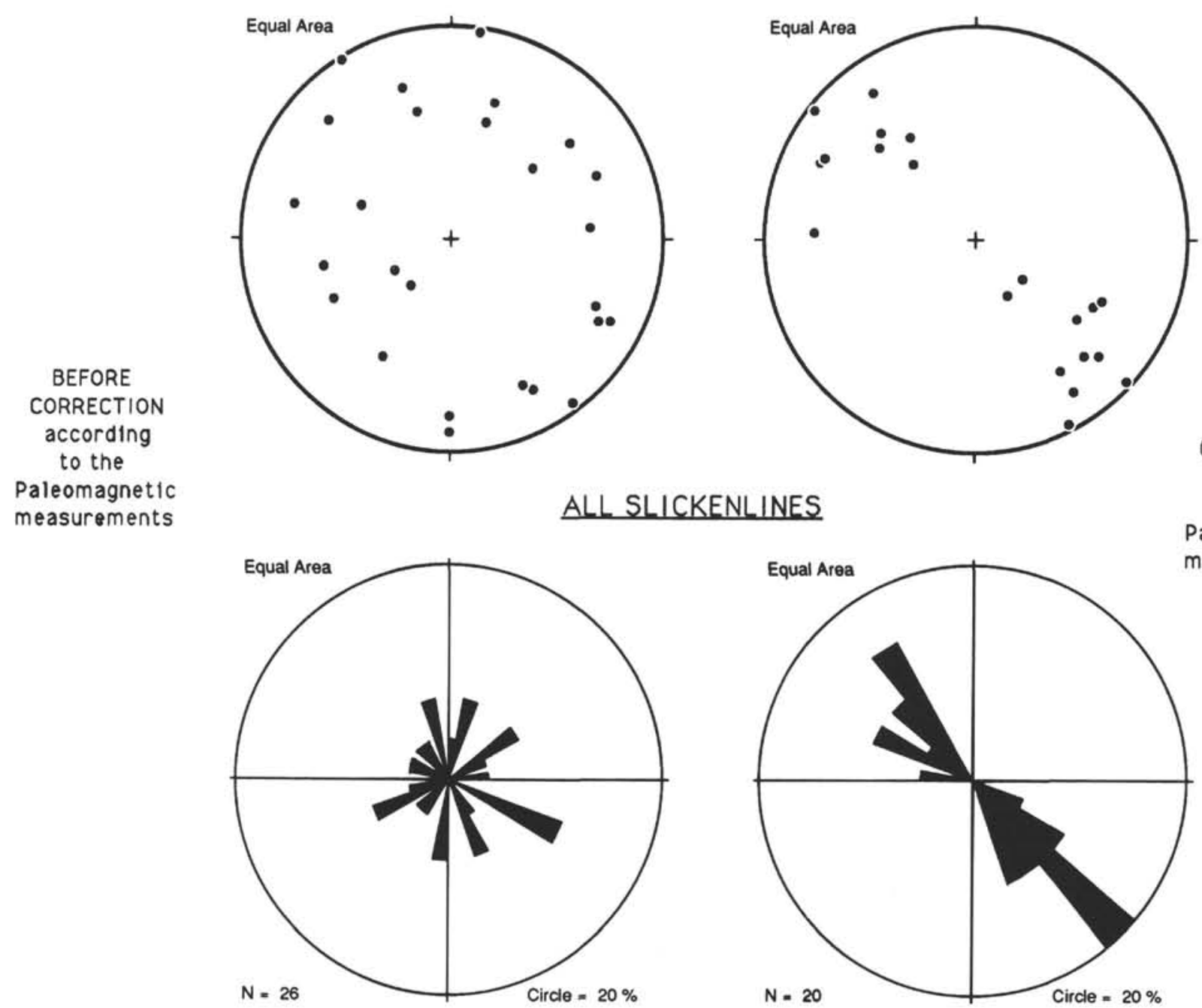

AFTER CORRECTION according to the Paleomagnetic measurements

Figure 4. Example of orientation by the use of paleomagnetic poles. Upper diagrams are stereograms of the slickenlines (equal area or Schmidt projection, lower hemisphere), and lower diagrams show the distribution of the slickenlines trends. Left diagrams represent "relative" trends in the core liner reference frame whereas right-side diagrams correspond to the geometry after correction of the drilling induced rotation, based on the paleomagnetic results.

culated reduced stress tensor should plot above the line representative of the friction law. This allows a determination of the friction coefficient and of the position of the origin $(\sigma=0)$ with respect to the circle diameter (Fig. 13).

As the friction law is linear, the magnitude of the shear stress cannot be estimated without further assumptions. One can assume the value of one of the effective principal stresses. In the present study and for the thrusting phase

$$
\sigma_{3}=\mathrm{P}_{\text {litho }}
$$

as $\sigma_{3}$ is always very close to vertical, but as fluid pressure is unknown, the corresponding effective stress

$$
\sigma_{3} *=\sigma_{3}-P_{\text {fluid }}
$$

is unknown. The method used by Angelier (1989) is to assume the failure curve and to use conjugate faults to determine the tangent of the Mohr circle to the failure envelope. The slope of the tangent normally decreases as $\sigma_{3}{ }^{*}$ increases (Griffith, 1924; Hoek and Bray, 1981). For large normal stresses, the slope at the tangent point should tend to equal the friction coefficient, and the angle between conjugate faults is of the order of $60^{\circ}$, as in sand. The angle between conjugate faults is also expected to decrease to zero as $\sigma_{3}{ }^{*}$ decreases and becomes negative to reach the tensile strength of the rock.

In this preliminary study, we do not go further in the mathematical analysis. However, some qualitative results can be obtained from the Mohr circles without additional unverified assumptions.

The number of faults in most of the fault populations used to determine the stress tensors is not sufficient to obtain reliable statistics from a Mohr diagram. We gathered the fault data into four groups; faults for which the angle between observed and predicted slickenlines is more than $20^{\circ}$ were discarded. The first Mohr diagram groups all cores (131-808C-11R to 131-808C-30R) situated below the frontal thrust, down to the trench to basin transition. The second group is situated around $800 \mathrm{~m}$ depth, near the transition from ash-bearing to ash-free hemipelagites (Cores 131-808C-49R, 131-808C-52R, 131808C-53R, 131-808C-56R). We did not consider data from Core 131$808 \mathrm{C}-51 \mathrm{R}$, as the strain is higher, and thus rotation of blocks is possible. The third and fourth groups lie just above or at décollement level. Group 3 corresponds to the main northwest-southeast compressive phase and includes data from the least disturbed sections of the décollement (Core 131-808C-69R) and compatible faults from Core 131-808C-64R. Group 4 corresponds to the transverse northeast-southwest compression and includes Core 131-808C-66R and compatible faults from Core 131-808C-64R. 
Table 2. Predicted apparent rotation of the magnetic declination produced at the Site 808 by a finite absolute motion of the Philippine Sea Plate since $2 \mathrm{Ma}$ and $5 \mathrm{Ma}$.

\begin{tabular}{cccccccc}
\hline & \multicolumn{2}{c}{ PSP/HS Eulerian pole } & & \multicolumn{3}{c}{ Azimuthal rotation } \\
\cline { 2 - 3 } Source (PSP/Eu rotation) & $\begin{array}{c}\text { Latitude } \\
{ }^{\circ} \mathrm{N}\end{array}$ & $\begin{array}{c}\text { Longitude } \\
{ }^{\circ} \mathrm{E}\end{array}$ & & $\begin{array}{c}\text { Angular velocity } \\
\text { degrees/Ma }\end{array}$ & $2 \mathrm{Ma}$ & $5 \mathrm{Ma}$ \\
\hline 1 & 35.9 & 141.6 & & 1.23 & 2.34 & 5.87 \\
2 & 37.3 & 142.4 & & 1.98 & 3.70 & 9.29 \\
3 & 47.9 & 158.0 & & 1.11 & 1.62 & 4.06 \\
\hline
\end{tabular}

Note: The finite rotations of the Philippine Sea Plate relative to the Hot Spot system (referred to as PSP/HS) are obtained by combining various models for Philippine Sea Plate/Eurasia PSP/EU) relative motion with the Eurasia/Hot Spot absolute rotation in the AMI-2 mode (Minster and Jordan, 1978): latitude $0.7^{\circ} \mathrm{N}$, longitude $23.2^{\circ} \mathrm{W}$, and angular velocity $0.038^{\circ} / \mathrm{Ma}$. Same sources and conventions as in Table 1 .

All four Mohr diagrams are very similar. Most data points (95\%) lie above a friction line of slope $35^{\circ} \pm 5^{\circ}(\mu=0.7)$. However, a few high angle faults are only compatible with a friction angle of $18^{\circ} \pm$ $8^{\circ}(\mu=0.32)$. The significance of these data is questionable, as one could actually be a normal fault (in group 3), two are slickenlined shear bands (in group 1) and thus may not follow a friction law. However such a low value of friction is in the range of experimental determinations for clays (Byerlee, 1978). There is no evidence that the hemipelagites, in which the décollement formed, have a lower friction coefficient than the sediments above.

One would expect that few reactivated faults are present; actually, most faults plot on the outer circle of the Mohr diagrams. Consequently we assumed that a majority of faults correspond to conjugate sets formed in the stress field calculated by the inversion method. The median value of the angle $2 \theta$ is considered as more representative of the angle between conjugate faults than the mean value because it is less sensitive to extreme values. It appears that the median $2 \theta$ decreases with depth from $60^{\circ}$ in group 1 to $40^{\circ}$ in group 2 and to about $35^{\circ}$ in groups 3 and 4 . The clusters of possible conjugate sets cover quite a large angular span (except for the group 3), as shown by the histograms in Figures $14 \mathrm{C}$ to $17 \mathrm{C}$. Therefore, an accurate determination of the angle between conjugate faults is impossible. But these values are a clear indication that the fault population between $760 \mathrm{mbsf}$ and the décollement (963 mbsf) contains more low angle faults than usual. We can exclude a flattening of the fault planes by porosity reduction during the burial because the maximum porosity reduction (about $10 \%$ ) since the onset of the compressive deformation results only in a slight change $\left(3^{\circ}\right)$ in $2 \theta$ angle. On the other hand, a very low (or negative) value of effective minimum stress, comparable to the tensile strength of the material (probably of the order of $1 \mathrm{MPa}$, to be compared with a lithostatic pressure of $20 \mathrm{MPa}$ at the décollement) can produce this effect. This implies a high pore pressure which can also account for the observation of a hydrofracturated siltstone at 788 mbsf (Byrne et al., this volume) and for a clastic dike at 813 mbsf (Taira et al., 1992). Another possibility is that décollement clays could be very anisotropic with respect to failure. The angle $2 \theta$ is close to the usual value of $60^{\circ}$ in group 1 , one would thus expect the effective minimum stress to be higher there, and, as they are situated at a shallower depth, the pore pressure $\mathrm{P}_{\mathrm{f}}$, and the pore pressure ratio $\left(\mathrm{P}_{f} / \mathrm{P}_{t}\right)$ should be lower. Group 2, around $800 \mathrm{mbsf}$, shows an intermediate behavior.

\section{DISCUSSION}

We showed that despite the young age of the offscraped sedimentary column, at least two kinds of compressive stress regimes can be derived from the inversion of the striated fault geometry. Both stress regimes have been active only above the décollement. Taking into account that the shortening parallel to the strike of the structures (frontal thrust and anticlinal axis) is restricted to a certain depth range where both shortening directions appear, we can produce two hypotheses. In the first one, we admit that the two different $\sigma_{1}$ axes correspond to successive well-characterized stress regimes, whereas in the second one, they occur alternatively within the same deformation stage. Unfortunately, no direct and unambiguous criterion of chronology between the two phases has been recorded. However, the structural interpretation of the reference seismic profile (Moore et al., 1990, and Fig. 2) provides some clues. One can notice that the upper part of the Shikoku Basin sequences has not a constant thickness between the décollement and the transition to the wedge-filling. A significant amount of tectonic thickening appears below the faultbend fold related to the frontal thrust and below the incipient faultbend fold related to the protothrust zone. To explain this unusual stress regime with a compressive axis $\sigma_{1}$ parallel to the strike of the frontal thrust, we could figure out that during the preliminary stages of the offscraping, thickening occurs first by formation of duplex structures in the overpressured layers between the actual décollement and the top of the Shikoku Basin sequences. If the compressive strain is not homogeneous along the strike of the duplexes, some along-strike compressive stresses can thus be produced. In the latest stage of the deformation, the thickening propagates with the frontal thrust at higher strain rates up to the surface.

\section{SUMMARY}

The main result of this study is probably to show that the brittle structures observed at Site 808 have a consistent geometry. The stress tensor inversion of oriented slickenlined fault planes allow us to state that most of the brittle deformation in the incipient stage of deformation at the toe of Nankai accretionary wedge has occurred only above the décollement level and in a compressional regime where the maximum principal stress axis $\left(\sigma_{1}\right)$ is horizontal and coincides with the local vector of the plate convergence. This statement was not unexpected. However, it is the first time we can claim it on a quantitative basis. A Mohr diagram analysis of the slickenlines related to their best-fitting tensor, suggests that failure could take place with higher fluid pressures not only in the $30 \mathrm{~m}$ thick décollement zone but also in a $200 \mathrm{~m}$ thick zone above the décollement.

\section{ACKNOWLEDGMENTS}

We greatly acknowledge J. Angelier for kindly providing two of us (S.L. and T.B.) with his stress tensor inversion programs. We acknowledge our colleagues B. Owens and R. Lu for discussions onboard and after the cruise about the proper use of the remanent magnetization for the core orientation. This manuscript benefited from discussions with X. Le Pichon, J.P. Gratier, and N. Chamot-Rooke. We are grateful to J. Angelier for his helpful comments and to one anonymous reviewer for his critical and constructive review.

\section{REFERENCES*}

Angelier, J., 1979. Determination of the mean principal directions of stresses for a given fault population. Tectonophysics, 56:T17-T26.

, 1984. Tectonic analysis of fault slip data sets. J. Geophys. Res., 9:5835-5848.

1989. From orientation to magnitudes in paleostress determinations using fault slip data. J. Struct. Geol., 11:37-50.

Angelier, J., and Manoussis, S., 1980. Classification automatique et distinction des phases superposées en tectonique de failles. C. R. Acad. Sci. Ser. 2 , 290:651-654.

*Abbreviations for names of organizations and publication titles in ODP reference lists follow the style given in Chemical Abstracts Service Source Index (published by American Chemical Society). 
Angelier, J., and Mechler, P., 1977. Sur une méthode graphique de recherche des contraintes principales également utilisable en tectonique et en séismologie: la méthode des dièdres droits. Bull. Soc. Geol. Fr., 19:1309-1318.

Angelier, J., Tarantola, A., Valette, B., and Manoussis, S., 1982. Inversion of field data in fault tectonics to obtain the regional stress. I. Single phase fault populations: a new method of computing the stress tensor. Geophys. J. R. Astron. Soc., 69:607-621.

Armijo, R., and Cisternas, A., 1978. Un problème inverse en microtectonique cassante. C. R. Acad. Sci. Ser. 2, 287:595-598.

Arthaud, F., and Mattauer, M., 1969. Exemples de stylolites d'origine dans le Languedoc, leurs relations avec la tectonique cassante. Bull. Soc. Geol. Fr., 11:738-744.

Barrier, E., 1985. Tectonique d'une chaîne de collision active: Taiwan [thesis]. Univ. Pierre et Marie Curie, Paris.

Bott, M.H., 1959. The mechanics of oblique slip faulting. Geol. Mag., 96:109-117.

Byerlee, J.D., 1978. Friction of rocks. Pure Appl. Geophys., 116:615-626.

Carey, E., and Brunier, B., 1974. Analyse numérique et théorique d'un modèle mécanique élémentaire appliqué à l'étude d'une population de failles. $C$. R. Acad. Sci. Ser. 2, 179:891-894.

Chamot-Rooke, N., Tamaki, K., and Kobayashi, K., 1989. Deskewed magnetic profiles of the Shikoku Basin and the past kinematics of the Philippine Sea Plate. Eos, 70:1365-1366. (Abstract)

Etchecopar, A., Vasseur, G., and Daignières, M., 1981. An inverse problem in microtectonics for the determination of the stress tensor from fault striation analysis. J. Struct. Geol., 3:51-65.

Gephart, J.W., and Forsyth, D.W., 1984. An improved method for determining the regional stress tensor using earthquake focal mechanism data: application to the San Fernando earthquake sequence. J. Geophys. Res., 89:9305-9320.

Griffith, A.A., 1924. The theory of rupture. In Biezeno, C.B., and Burgers, J.M. (Eds.), Proc. 1st. Int. Congr. Appl. Mech., 54-63.

Gripp, A.E., and Gordon, R.G., 1990. Current plate velocities relative to the Hotspots incorporating the NUVEL-1 global plate motion model. Geophys. Res. Lett., 17:1109-1112.

Hoek, E., and Bray, J.W., 1981. Rock Slope Engineering (5th ed.): London (Inst. of Mining and Metallurgy).

Huchon P., 1986. Comments on "Kinematics of the Philippine Sea plate" by Ranken, B., et al. Tectonics, 5:165-168.

Huchon, P., and Angelier, J., 1987. From subduction to collision: the SurugaFujigawa belt, Izu collision zone. Bull. Soc. Geol. Fr., 3:511-521.

McClay, K., 1987. The Mapping of Geological Structures: Milton Keynes, England (Open University Press).

Mercier, J.L., Carey, E., Philip, H., and Sorel, D., 1976. Les déformations plio-quaternaires dans l'arc égéen et leurs relations avec la sismicité. Bull. Soc. Geol. Fr., 18:355-372.

Minster, J.B., and Jordan, T.H., 1978. Present-day plate motions. J. Geophys. Res., 83:5331-5354.
Moore, G.F., Shipley, T.H., Stoffa, P.L., Karig, D.E., Taira, A., Kuramoto, S., Tokuyama, H., and Suyehiro, K., 1990. Structure of the Nankai Trough accretionary zone from multichannel seismic reflection data. J. Geophys. Res., 95:8753-8765.

Perroud, H., 1982. The change of palaeomagnetic vector orientation induced by Eulerian rotations: applications for the relative rotations of Spain and Europe. Tectonophysics, 81:T15-T22.

Petit, J.P., Proust, F., and Tapponnier, P., 1983. Critères de sens de mouvement sur les miroirs de failles en roches non calcaires. Bull. Soc. Geol. Fr., 25:589-608.

Ranken, B., Cardwell, R.K., and Karig, D.E., 1984. Kinematics of the Philippine Sea Plate. Tectonics, 3:555-575.

Seno, T., 1977. The instantaneous rotation of the Philippine Sea plate relative to the Eurasian plate. Tectonophysics, 42:209-226.

Seno, T., and Maruyama, S., 1984. Paleogeographic reconstruction and origin of the Philippine Sea. Tectonophysics, 102:53-84.

Seno, T., Moriyma, T., Stein, S.A., Woods, D.F., and Demets, C., 1987. Redetermination of the Philippine Sea plate motion. Seismol. Soc. Jpn. Progr. and Abstr., 1:86.

Shipboard Scientific Party, 1991. Site 808. In Taira, A., Hill, I., Firth, J.V., et al., Proc. ODP, Init. Repts., 131: College Station, TX (Ocean Drilling Program), 71-272.

Taira, A., Hill, I., Firth, J., Berner, U., Brückmann, W., Byrne, T., Chabernaud, T., Fisher, A., Foucher, J.-P., Gamo, T., Gieskes, J., Hyndman, R., Karig, D., Kastner, M., Kato, Y., Lallement, S., Lu, R., Maltman, A., Moore, G., Moran, K., Olaffson, G., Owens, W., Pickering, K., Siena, F., Taylor, E., Underwood, M., Wilkinson, C., Yamano, M., and Zhang, J., 1992. Sediment deformation and hydrogeology of the Nankai accretionary prism: synthesis of shipboard results of ODP Leg 131. Earth Planet. Sci. Lett., 109:431-450.

Twiss, R.J., Prozman, G.M., and Hurst, S.D., 1991. Theory of slickenline patterns based on the velocity gradient tensor and microrotation. Tectonophysics, 186:215-239.

Vacquier, V., and Uyeda, S., 1967. Paleomagnetism of nine seamounts in the western Pacific and of three volcanoes in Japan. Tokyo Daigaku Jishin Kenkyusho Iho [Bull. Earthquake Res. Inst., Univ. Tokyo], 45:814-848.

Wallace, R.E., 1951. Geometry of shearing stress and relation to faulting. $J$. Geol., 59:118-130.

Date of initial receipt: 7 February 1992

Date of acceptance: 19 October 1992

Ms 131SR-109 


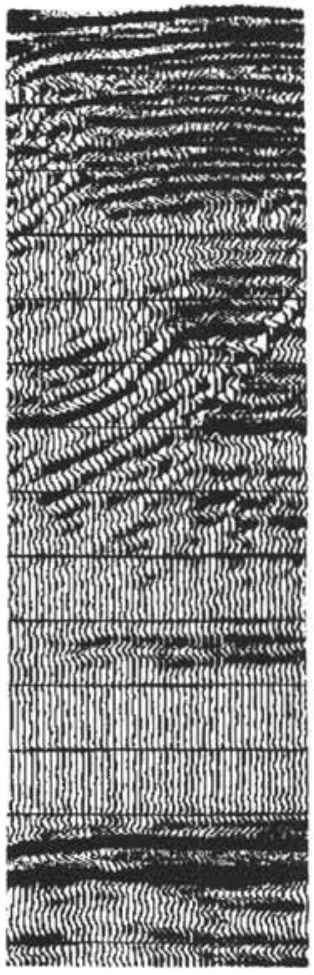

DEPTH (mbsn

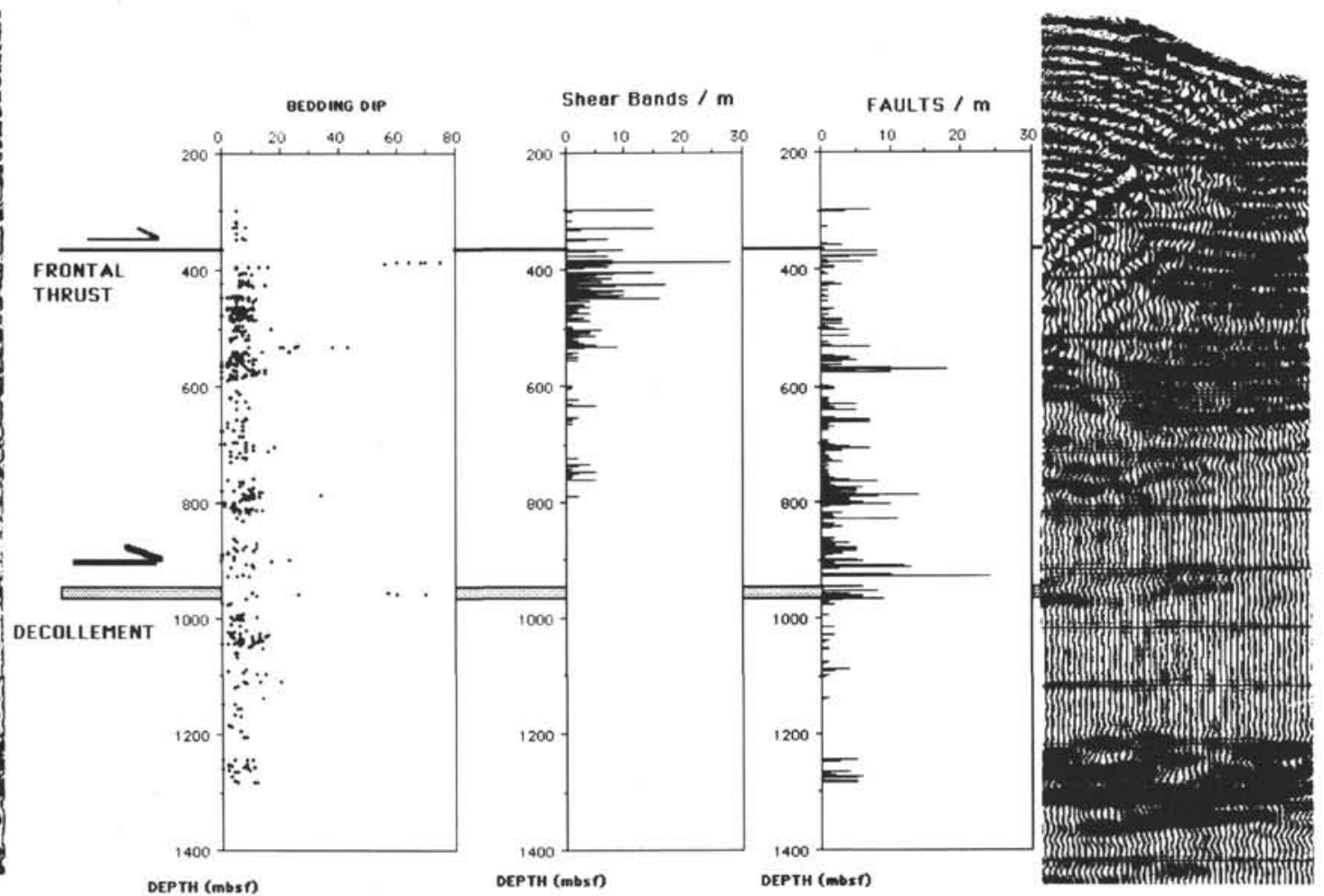

Figure 5. Depth distribution of the structural features along the Hole $808 \mathrm{C}$ (bedding dip, faults, and deformation bands).

Table 3. Main results of the stress tensor inversion of selected populations of slickenlined faults at Hole 808C. Ratio $\Phi$ is $\left(\sigma_{2}-\sigma_{3}\right) /\left(\sigma_{1}-\sigma_{3}\right)$.

\begin{tabular}{|c|c|c|c|c|c|c|c|c|c|}
\hline \multirow[b]{2}{*}{ Core } & \multicolumn{2}{|c|}{ Depth (mbsf) } & \multirow{2}{*}{$\begin{array}{l}\text { Number } \\
\text { of faults }\end{array}$} & \multicolumn{2}{|c|}{$\sigma_{1}$} & \multicolumn{2}{|c|}{$\sigma_{3}$} & \multirow{2}{*}{$\begin{array}{l}\text { Mean } \\
\text { angle }\end{array}$} & \multirow[b]{2}{*}{ Ratio 4} \\
\hline & $\min$ & $\max$ & & Trend & Plunge & Trend & Plunge & & \\
\hline \multicolumn{10}{|l|}{$131-808 \mathrm{C}$ - } \\
\hline $11 \mathrm{R}-13 \mathrm{R}$ & 395 & 424 & 7 & 316 & 02 & 220 & 68 & 13 & 0.05 \\
\hline $14 \mathrm{R}$ & 424 & 434 & 8 & 317 & 01 & 214 & 84 & 13 & 0.35 \\
\hline $15 \mathrm{R}-18 \mathrm{R}$ & 434 & 472 & II & 315 & 04 & 179 & 84 & 11 & 0.30 \\
\hline $20 R-23 R$ & 482 & 520 & 9 & 304 & 13 & 147 & 76 & 11 & 0.74 \\
\hline $29 \mathrm{R}$ & 569 & 578 & 16 & 311 & 06 & 203 & 71 & 15 & 0.08 \\
\hline $30 \mathrm{R}$ & 578 & 580 & 14 & 126 & 07 & 269 & 81 & 13 & 0.55 \\
\hline $38 \mathrm{R}-\mathrm{N}$ & 655 & 664 & 10 & 009 & 62 & 109 & 05 & 17 & 0.74 \\
\hline $49 \mathrm{R}$ & 761 & 770 & 9 & 297 & 02 & 150 & 87 & 15 & 0.39 \\
\hline $50 \mathrm{R}-\mathrm{N}$ & 770 & 780 & 7 & 082 & 62 & 313 & 18 & 15 & 0.34 \\
\hline $53 R$ & 799 & 809 & 23 & 135 & 05 & 250 & 79 & 29 & 0.24 \\
\hline $55 \mathrm{R}$ & 819 & 828 & 6 & 115 & 81 & 273 & 08 & 13 & 0.10 \\
\hline $56 \mathrm{R}$ & 828 & 838 & 11 & 138 & 00 & 233 & 84 & 13 & 0.001 \\
\hline $64 R$ & 905 & 915 & 13 & 136 & 04 & 039 & 61 & 06 & 0.001 \\
\hline $64 \mathrm{R}-\mathrm{ul}$ & 905 & 915 & 18 & 292 & 05 & 051 & 79 & 10 & 0.05 \\
\hline $64 \mathrm{R}-\mathrm{u} 2$ & 905 & 915 & 17 & 252 & 04 & 116 & 85 & 08 & 0.24 \\
\hline $66 \mathrm{R}$ & 925 & 934 & 29 & 252 & 02 & 356 & 83 & 15 & 0.14 \\
\hline $69 \mathrm{R}$ & 954 & 963 & 12 & 132 & 07 & 322 & 83 & 15 & 0.52 \\
\hline
\end{tabular}



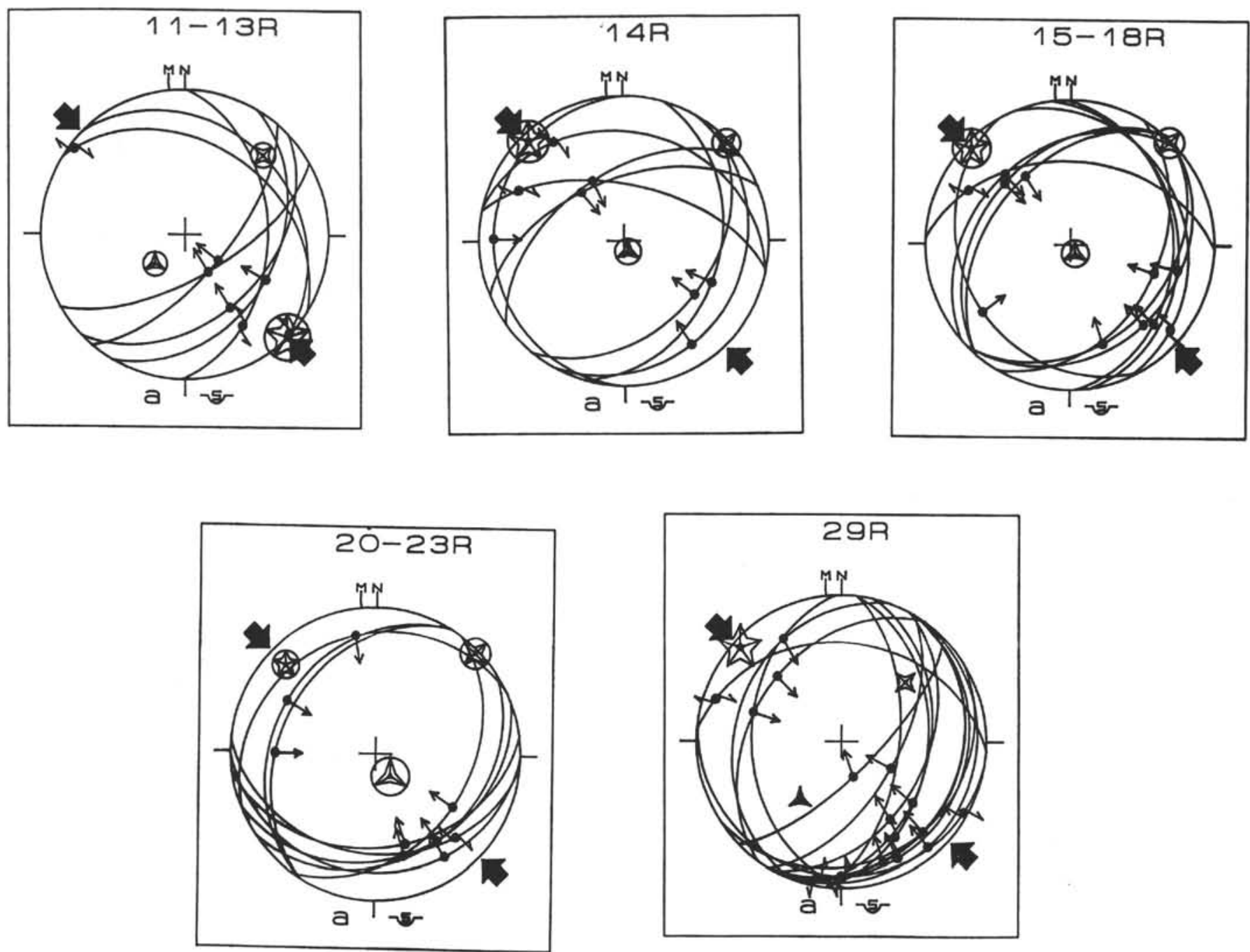

Figure 6. Stereogram representation of the slickenlined faults of some selected cores from Hole $808 \mathrm{C}$ with the principal axes of the stress tensor obtained by inversion. These axes $\left(\sigma_{3}, \sigma_{2}, \sigma_{1}\right)$ are shown by stars with 3,4 , and 5 arms, respectively. 

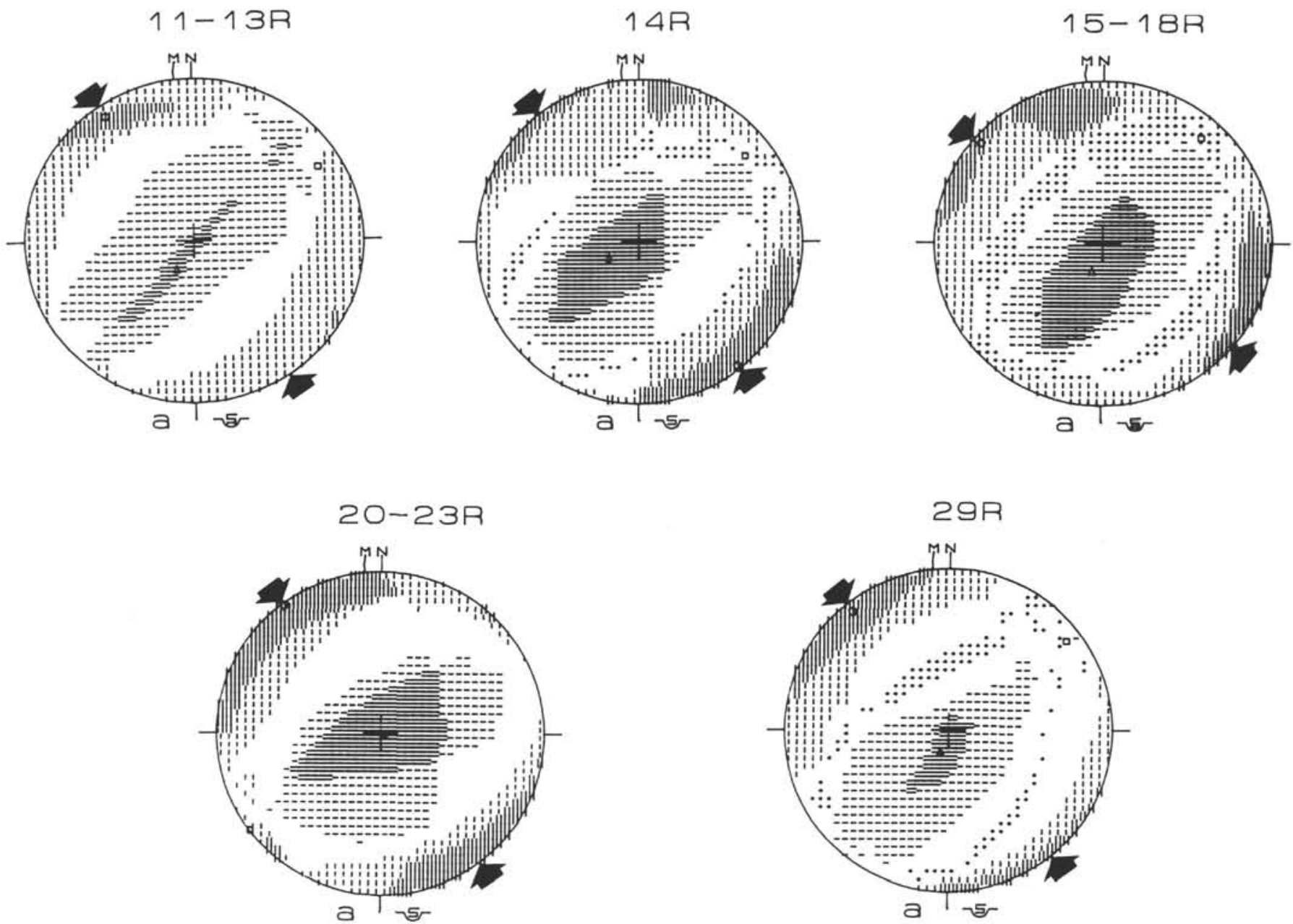

Figure 7. Estimates of the principal stresses by the means of the right-angle dihedra method. Same selection of sites as in Figure 6 . Solid arrows show the mean $\sigma_{1}$ direction. 



Figure 8. Stress tensor inversion of slickenlined faults. Left diagrams (a) are stereograms of the actual data sets. Central diagrams (b) show the principal axes of the best-fitting tensor (same meaning as in Fig. 6). Right diagrams (c) display the maximum shear stress direction along the actual fault planes as predicted for the best-fitting tensor. Core $30 \mathrm{R}$ at $570 \mathrm{mbsf}$ belongs to a transitional sequence between the hemipelagic muds and the silt turbidites. Core $131-808 \mathrm{C}-53 \mathrm{R}$ at $800 \mathrm{mbsf}$ belongs to the upper Shikoku Basin sequence and 131-808C-56R at $820 \mathrm{mbsf}$ belongs to the ash-free lower Shikoku Basin sequence. 

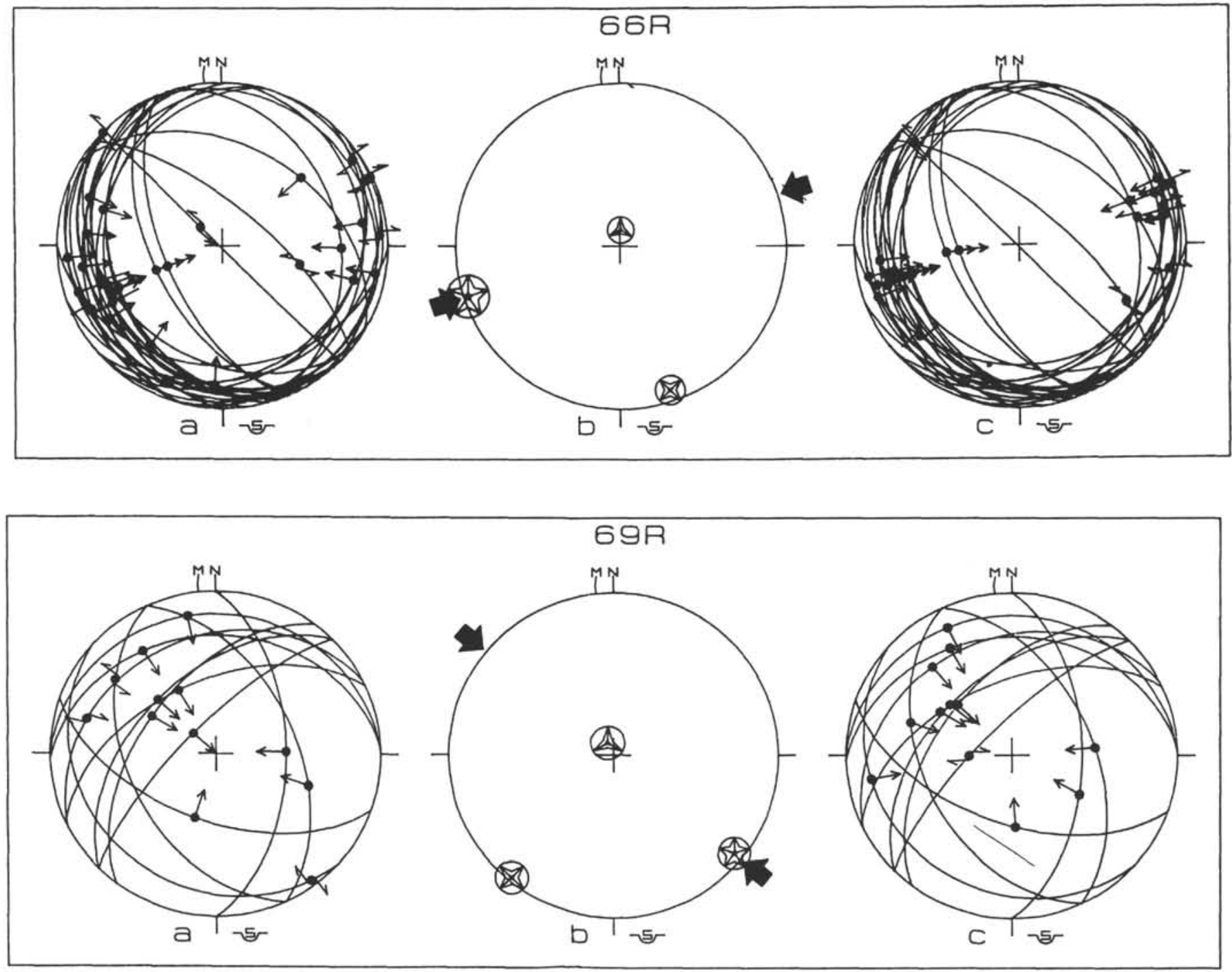

Figure 9. Stress tensor inversion of slickenlined faults above the décollement (Core 131-808C-66R, at $925 \mathrm{mbsf}$ ) and inside the décollement zone (Core 131-808C-69R at $955 \mathrm{mbsf}$ ). Same diagrams as in Figure 8. 

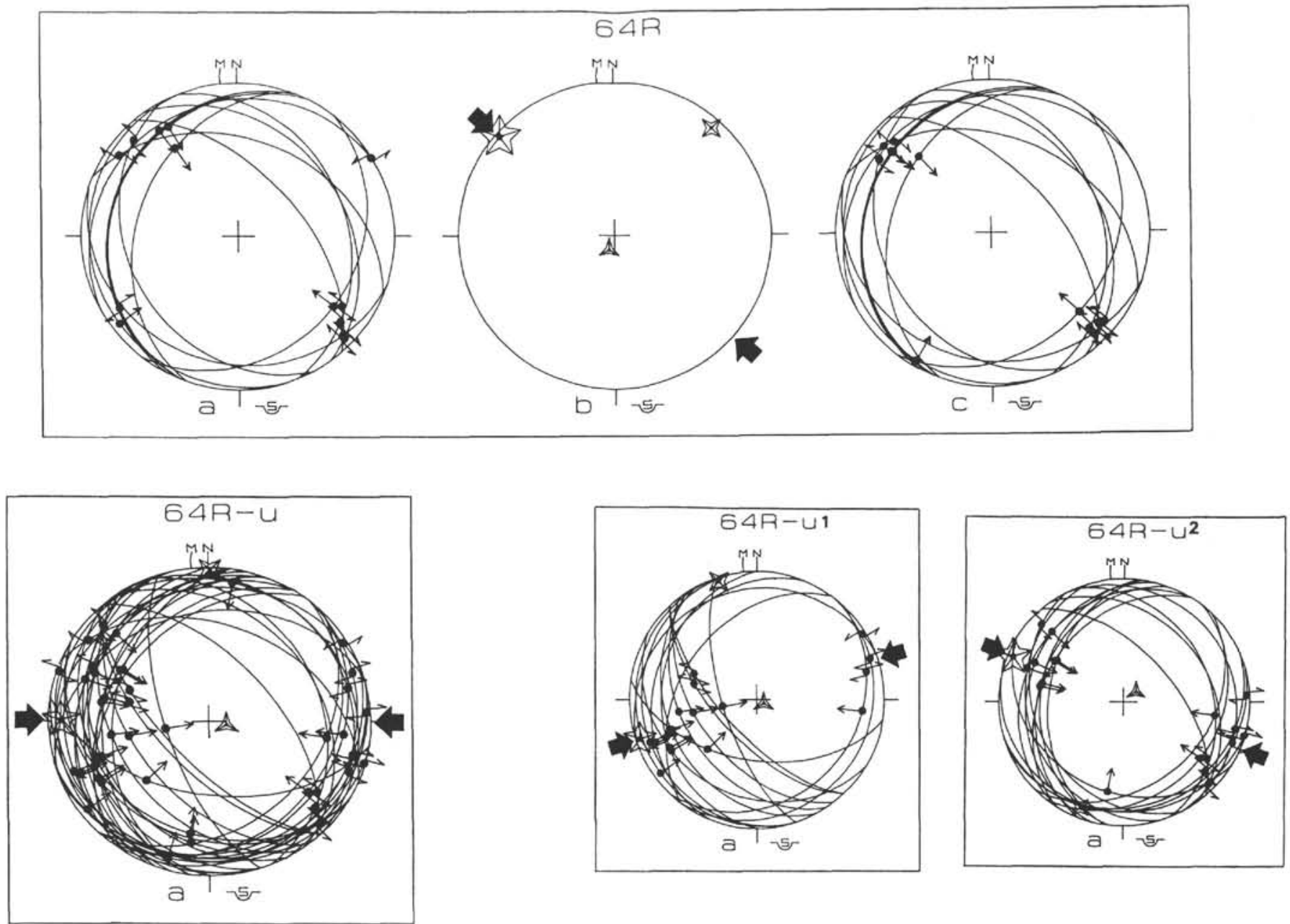

Figure 10. Stress tensor inversion of slickenlined faults and automatic sorting of tectonic phases above the décollement (Core 131-808C-64R, at 905 mbsf). Upper diagrams (64R) show the results of the inversion of the faults whose sense of motion is known as reverse. Diagram 64R-u corresponds to faults with unknown sense of motion (the sense has been assumed to be reverse in the lower left diagram). Diagrams 64R-ul and 64R-u2 show the two homogeneous fault populations sorted with the method of Angelier and Manoussis (1980). 

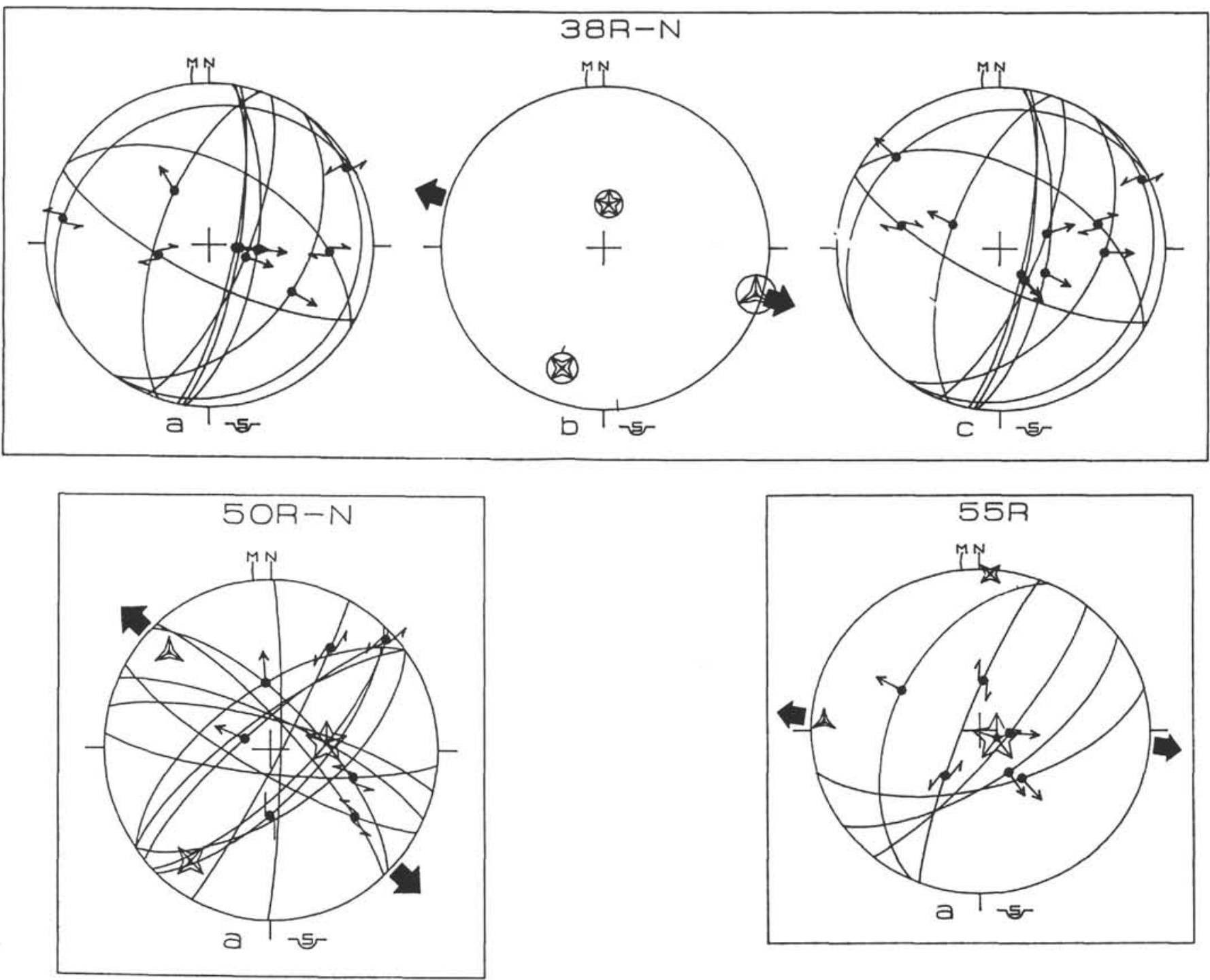

Figure 11. Some examples of stress tensor inversion of consistent fault data sets related to the extensional tectonic event. Upper diagram is similar to Figure 8 (131-808C-38R, at $655 \mathrm{mbsf}$ is in the Upper Shikoku Basin sequence). Cores 131-808C-50R ( $770 \mathrm{mbsf})$ and 131-808C-55R ( $820 \mathrm{mbsf})$ are located at the base of the Upper Shikoku Basin sequence. 


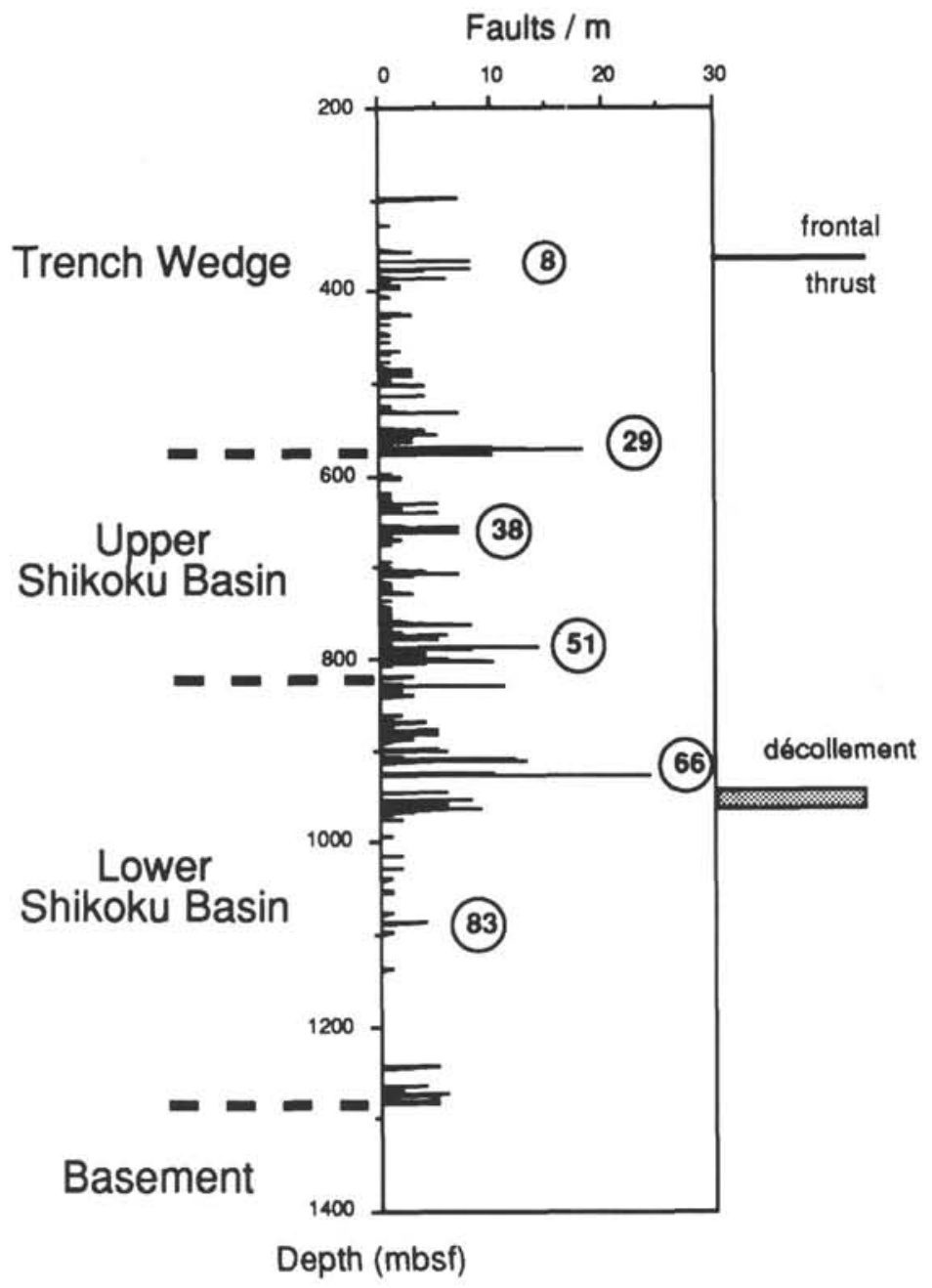

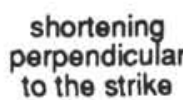

to the strike

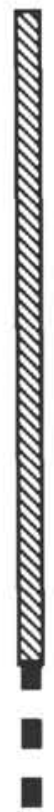

normal

faulting

Figure 12. Depth distribution of the three main groups of stress tensors along Hole 808C.

Table 4. Stress parameters determined from Mohr diagrams.

\begin{tabular}{lccccccc}
\hline $\begin{array}{c}\text { Group } \\
\text { of cores }\end{array}$ & $\begin{array}{c}\text { Depth } \\
\text { range } \\
\text { (mbsf) }\end{array}$ & $\begin{array}{c}\text { Number of } \\
\text { faults }\end{array}$ & $\Phi$ & $\begin{array}{c}\omega \\
100 \%\end{array}$ & $\begin{array}{c}\omega \\
95 \%\end{array}$ & $\begin{array}{c}\mu=\tan \omega \\
95 \%\end{array}$ & $2 \theta$ \\
\hline Group 1 & $394-587$ & 54 & 0.29 & $10^{\circ}$ & $35^{\circ}$ & 0.7 & $60^{\circ}$ \\
Group 2 & $760-809$ & 31 & 0.20 & - & $30^{\circ}$ & 0.58 & $40^{\circ}$ \\
Group 3 & $906-963$ & 31 & 0.11 & $18^{\circ}$ & $38^{\circ}$ & 0.78 & $34^{\circ}$ \\
Group 4 & $906-935$ & 32 & 0.14 & $25^{\circ}$ & $32^{\circ}$ & 0.62 & $37^{\circ}$ \\
\hline
\end{tabular}




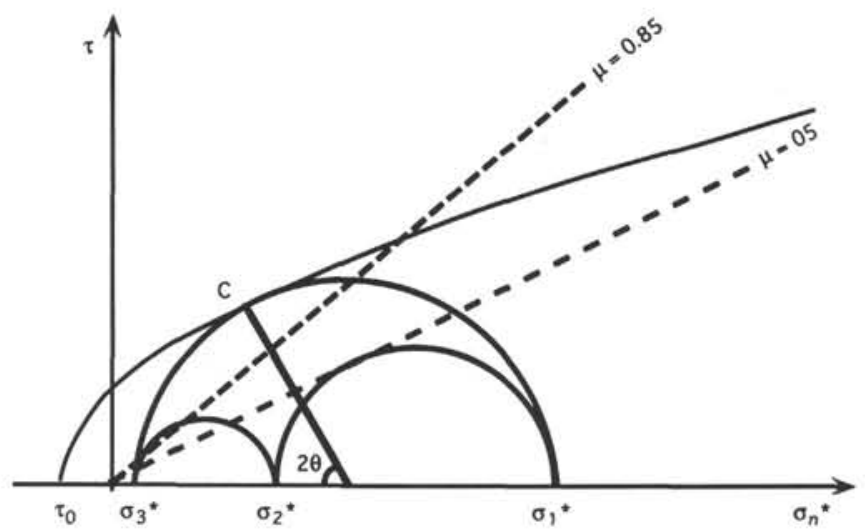

Figure 13. Dimensionless Mohr diagram (from Angelier, 1989). $\sigma_{n^{*}}=\sigma_{n}-$ Pfluid is the effective normal stress, $\tau$ is shear stress. Friction lines (dashed) are given for extreme friction values according to Byerlee (1978). Parameter $\Phi=\left(\sigma_{1^{*}}-\sigma_{3^{*}}\right) /\left(\sigma_{2^{*}}-\sigma_{3^{*}}\right)$ is determined from tensor inversion. As theory predicts that all faults should plot in the part of the Mohr circle above the friction line, friction coefficient $\mu$ and parameter $\Psi=\sigma_{3^{*}} / \sigma_{1^{*}}$ can be determined from the diagram. The failure curve (continuous), given as an example, follows Griffith's law (1924). Point C refers to conjugate fault systems. The angle between conjugate faults is $2 \theta$. Note however that in the studied case, this particular failure criterion does not predict $2 \theta$. When $\sigma_{3} *$ decreases, for example due to a rise in pore pressure, $2 \theta$ and $\Psi$ decrease.

A

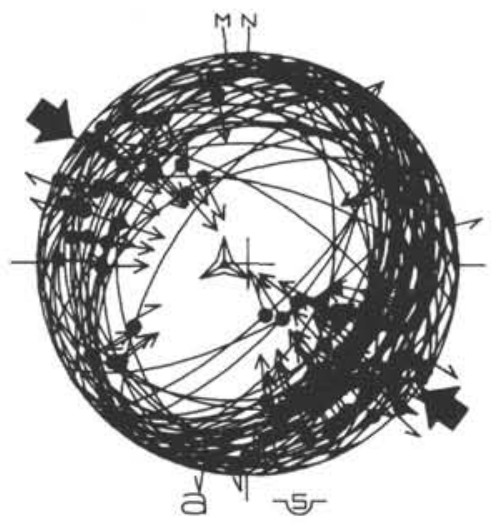

$808 C$ group I

a ᄀ5
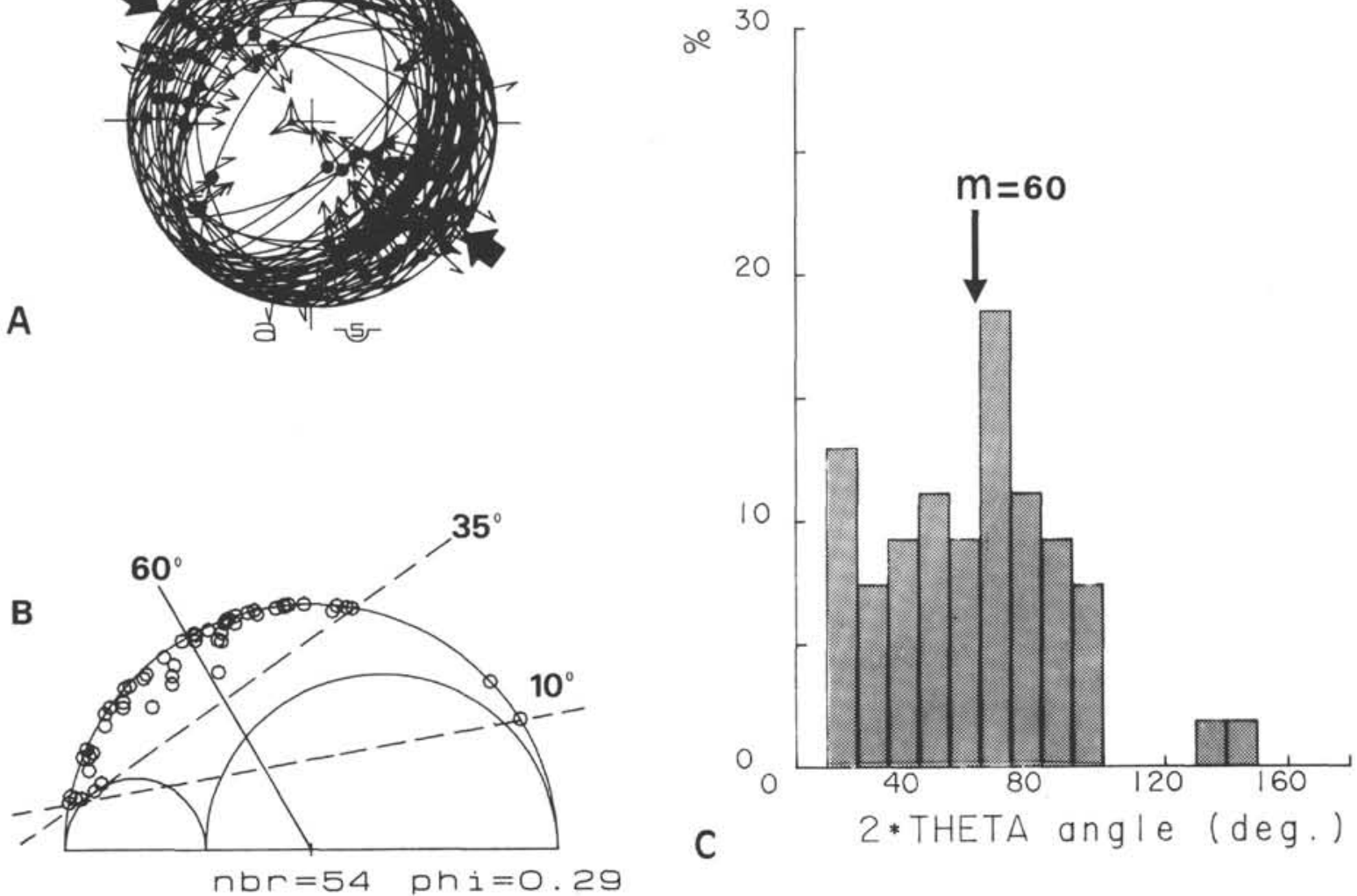

Figure 14. Characteristics of Mohr circles for the group of cores number 1 (Cores 131-808C-11R to 131-808C-30R). A. Slickenlined faults distribution and best-fitting composite tensor. B. Dimensionless Mohr circle; the slope of the friction line (dashed line) is $\omega=10^{\circ}$ to $\omega=$ $35^{\circ}$. The angle between conjugate faults (solid line), determined as the median of the distribution, is $2 \theta=60^{\circ}$. C. Distributions of the angles $2 \theta$, showing the median $\mathrm{m}=60^{\circ}$. 
A

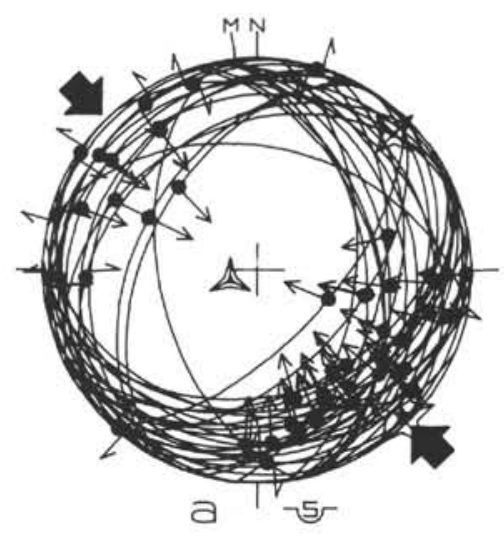

808 group 2
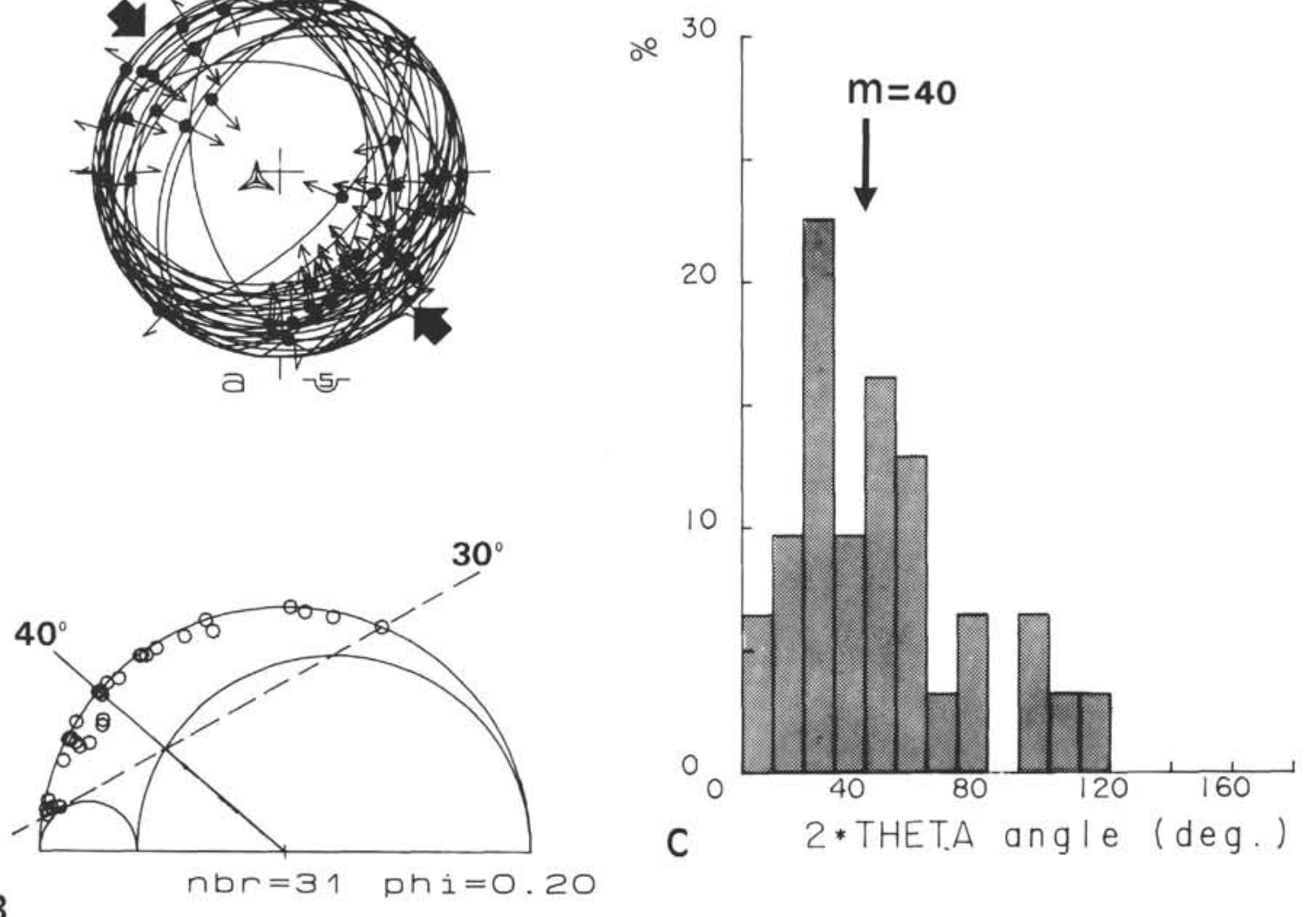

Figure 15. Same figure as Figure 14 for the group 2 (Cores 131-808C-49R to 131-808C-49R). The slope of the friction line (dashed line) is $\omega=30^{\circ}$. The angle between conjugate faults (solid line) is $2 \theta=40^{\circ}$. 
A
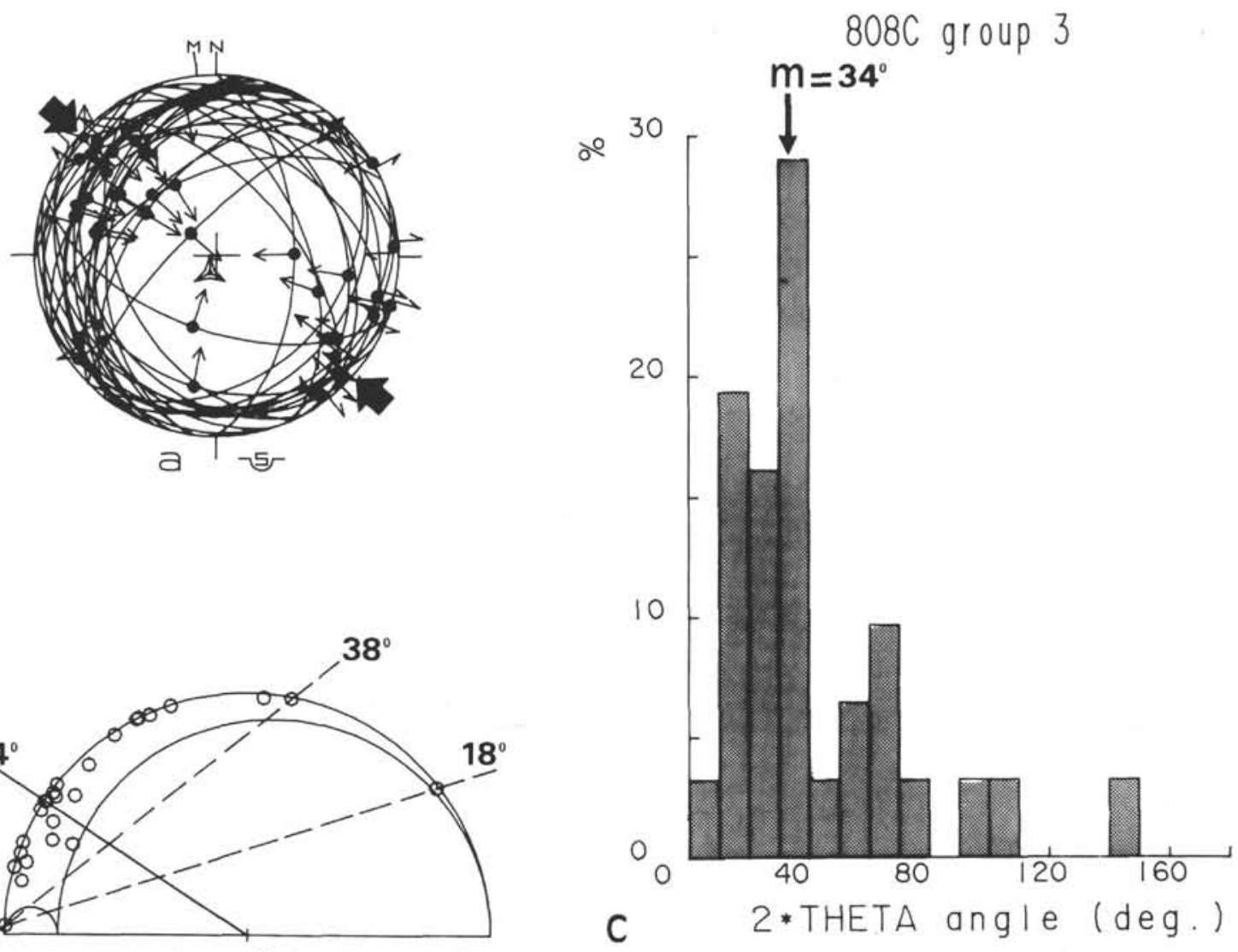

B

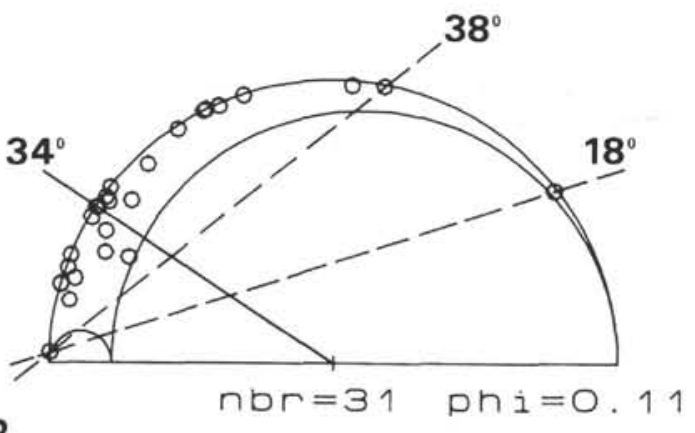

Figure 16. Same figure as Figure 14 for the group 3 (Cores 131-808C-64R to 131-808C-69R), typical from shortening perpendicular to the strike of the frontal thrust near the décollement. The slope of the friction line (dashed line) is $\omega=18^{\circ}$ to $\omega=38^{\circ}$. The angle between conjugate faults (solid line) is $2 \theta=34^{\circ}$. 

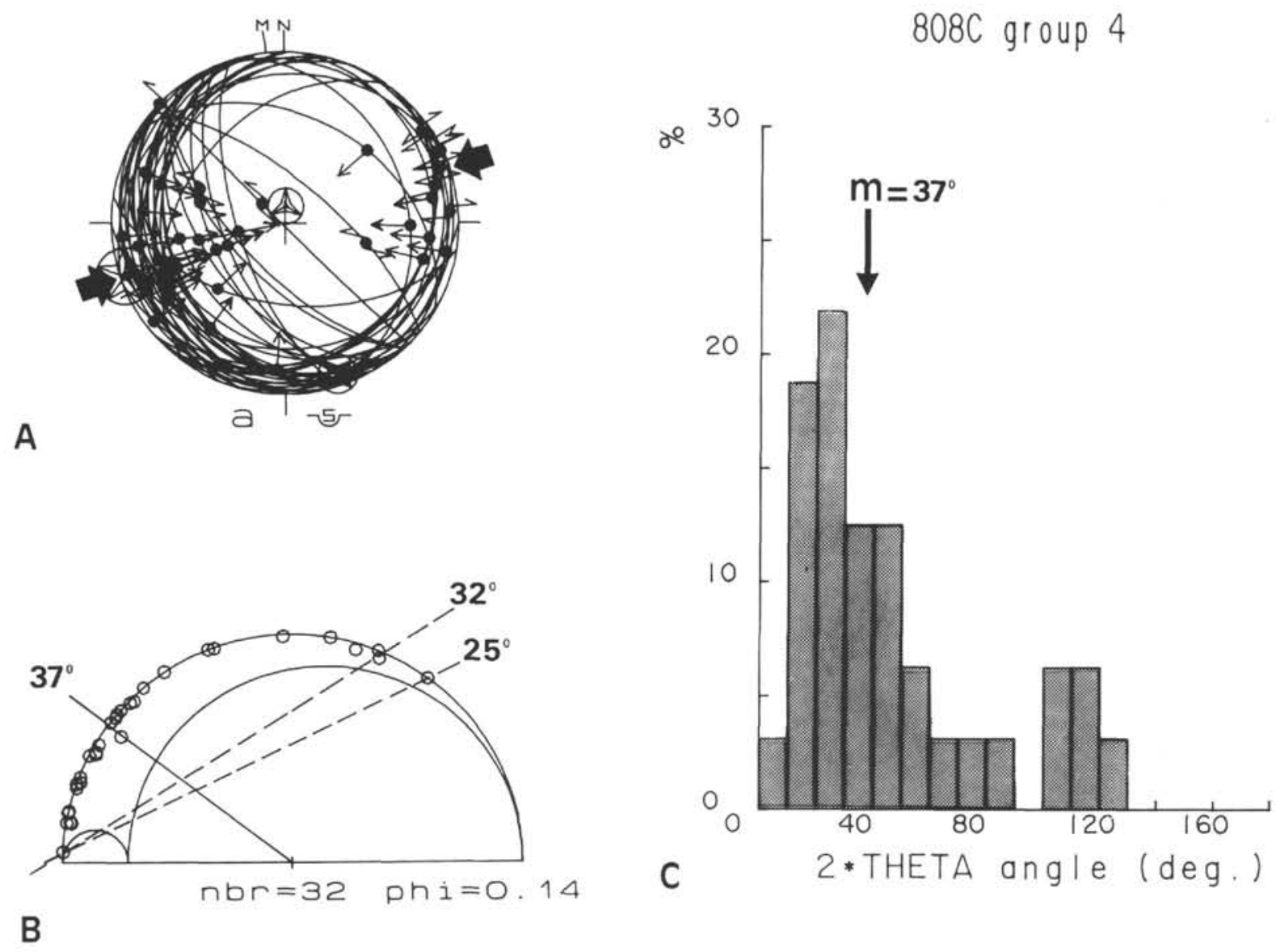

Figure 17. Same figure as Figure 14 for the group 4 (Cores 131-808C-64R to 131-808C-66R), typical from shortening parallel to the strike of the frontal thrust near the décollement. The slope of the friction line (dashed line) is $\omega=25^{\circ}$ to $\omega=32^{\circ}$. The angle between conjugate faults (solid line) is $2 \theta=37^{\circ}$. 